THE BOARD OF DIRECTORS AND DIVIDEND POLICY: THE EFFECT OF GENDER DIVERSITY

\author{
María Consuelo Pucheta-Martínez \\ Assistant Professor \\ University Jaume I \\ Department of Finance and Accounting \\ Campus del Riu Sec, S/n \\ 46017-Castellón- \\ Spain \\ e-mail:pucheta@uji.es \\ Inmaculada Bel-Oms \\ $\mathrm{PhD}$ \\ University Jaume I \\ Department of Finance and Accounting \\ Campus del Riu Sec, S/n \\ 46017-Castellón- \\ Spain \\ e-mail: ibel@uji.es
}




\title{
THE BOARD OF DIRECTORS AND DIVIDEND POLICY: THE EFFECT OF GENDER DIVERSITY
}

\begin{abstract}
In this paper we aim to study the impact on dividends policy of gender diversity on the board of directors (hereinafter BD). We hypothesise that the proportion of women directors, the proportion of independent, institutional and executive female directors, and the percentage of shares held by female directors on BD, have an impact on the dividends policy of Spanish companies. Our findings, analysing the whole sample, show that the proportion of female directors, and shares held by female directors, are positively associated with dividend payout, while the percentage of institutional female directors has a negative impact. The percentage of independent and executive female directors has no effect on dividend payout. When companies with losses are removed from the sample, the findings report that the percentage of female directors on $\mathrm{BD}$ and the percentage of independent female directors impact positively on dividend policy, while the percentage of institutional and executive female directors has a negative effect. The proportion of shares held by female directors on BD does not have an effect on dividend payout when only companies with profits are examined. Thus, the results confirm that gender diversity has an influence on dividend payout, so the existing legislation should encourage more participation by women in governing bodies. Our evidence supports the Act for Effective Equality between Women and Men, which establishes that listing companies have to achieve a quota of $40 \%$ of women in decision-making bodies by 2015 .
\end{abstract}

Key words: Corporate governance, Gender diversity, Dividend policy, Board of Directors, Gender quota

JEL Codes: G34, G35, M14,

\section{INTRODUCTION}

Agency theory argues that the separation between the control and ownership of the organization causes information asymmetries between shareholders and managers, which 
generate agency costs. The payment of dividends is considered one of the most important mechanisms to reduce or mitigate agency costs (Jensen, 1986; Byoun et al., 2013; Van Pelt, 2013). This is consistent with Ross (1977) and Bhattacharya (1979), who reported that companies with high levels of information asymmetries paid higher dividends because they may signal their future forecasts to stockholders.

Prior evidence analyses the influence on dividend payout of ownership concentration (Chen et al., 2005; Erol and Tirtiroglu, 2011), outside directors (Al-Najjar and Hussainey, 2009; SetiaAtmaja, 2010), taxes on dividends (Amihud and Murgia, 1997), future earnings (Flint et al., 2010; Vermeulen, 2011) and investor protection (La Porta et al., 2000), among others. However, academic literature on dividend policy has paid little attention to other features, including gender diversity.

Academic literature based on corporate governance shows that gender diversity on corporate boards may influence the supervision and control of the board's activities (Erhardt et al., 2003; Huse and Solberg, 2006; Rose, 2007; Adams and Ferreira, 2009; Huse et al., 2009; Nielsen and Huse, 2010). In this sense, most previous research provides evidence that females on boards of directors (hereinafter BD) have an important effect on financial reporting quality (Gulzar and Wang, 2011; Qi and Tian, 2012), fostering good corporate practice (Rogelberg and Rumery, 1996; Burgess and Tharenou, 2002) and firm performance (Shrader et al., 1997; Adams and Ferreira, 2003; Carter et al., 2003; Catalyst, 2004; Farrel and Hersch, 2005; Krishnan and Park, 2005; Campbell and Mínguez-Vera, 2008), among others. Therefore, given the significance of female on corporate boards in allocating capital to organizations, the role played by them in firm governance (Campbell and Mínguez-Vera, 2008; Terjesen et al., 2009), and the scant research performed combining gender diversity on BDs and dividend payment (Wellalage et al., 2012; Van Pelt, 2013), an understanding of how gender diversity on BDs affects dividend policy is undoubtedly needed. Thus, we aim at contributing to the 
growing literature on the role of women in corporate governance and, more concretely, to analyse whether gender diversity on BDs has an effect on the dividend policy of the companies.

This analysis contributes to previous literature by showing that gender diversity on BD influences the dividend policy of firms. Concretely, when considering jointly companies with profits and losses, the proportion of women directors, the proportion of institutional female directors and the percentage of shares held by female directors have an influence on dividend payment. When companies with losses are removed from the sample, the findings show that the proportion of women and of independent, institutional and executive female directors on $\mathrm{BD}$ drives an effect on dividend policy, but the percentage of shares held by women reports a lack of significance.

Our evidence supports the Spanish Law (Act 3/2007 of 22 March, for Effective Equality between Women and Men), issued in 2007, which is based on the premise that corporate boards' female quote should be $40 \%$. The Spanish legislator allows listing companies to achieve this gender quota by 2015 , so the current legislation should encourage more participation by women in governing bodies. Nevertheless, the Spanish progress is still too slow to meet the government's 2015 goal and therefore, for the quota to be met, we recommend more effective equality plans within companies, combined with stronger government sanctions. Secondly, our study provides evidence that gender diversity on BDs can alleviate the agency problem of free cash flow by monitoring and resolving the managershareholder conflict in an effective way; this is particularly true in the Spanish context, where two important agency problems are currently weak, namely shareholder rights and low management ownership. Thirdly, our results suggest that gender diversity on boards yields benefits to shareholders through its effect on dividend policy, and further provides evidence on the factors that affect dividend policy. This may be useful for current and potential 
shareholders of listing firms to know more deeply the dividends policies of the companies in which they invest. Finally, Spain is a good context in which to examine the effect of gender diversity on BDs on dividend policies, since most of the studies about dividend policy refer to non-European countries (Bathala and Rao, 1985; Zhou and Ruland, 2006; Rakotomavo, 2010; Gupta and Parua, 2012; Said, 2013).

The structure of this paper is as follows. After this introduction, the second section focuses on the institutional background. The third section describes the theoretical background, while in the fourth section the previous literature is reviewed and the hypotheses are developed. The fifth section describes the sample, methodology and variables used in the study; the sixth section reports the obtained findings. In the final section, we discuss the conclusions, the limitations inherent to this study and the future lines of research.

\section{INSTITUTIONAL SETTING}

The recent worldwide financial crisis has led to the international financial system losing its credibility. The incorporation of Spain into the Eurozone led to a reduction in interest rates that expanded the construction sector and increased private consumption and real estate investment through credit, among other consequences. The year unemployment rate (YUR) was reduced when the economic boom began, but when it stopped the YUR returned to its previous level. According to the National Institute of Statistics (INE, 2015), the YUR in Spain was $8.45 \%$ in 2006 while it was $24.44 \%$ in 2014 . The Spanish financial crisis has caused serious problems for economic performance, labour productivity and employment.

Corporate governance system in Spain is characterised by low independence on boards, the presence of a few large shareholders, passive market control, capital markets less developed, high ownership concentration and a one-tier board system (all directors, executives and nonexecutives form one board). 
Spain has undergone significant legal and institutional changes in order to increase the transparency of stock markets and to protect minority shareholders. As a consequence, regulators have published a series of codes of corporate good governance: Olivencia (1998), Aldama (2003) and the Conthe Code (2006), updated the last one in 2015. All these codes are based on the 'comply or explain' principle in order to enforce the corporate governance rules. On the other hand, it is worth noting that the growth of gender diversity on Spanish boards is influenced by the continuous socio-economic, political and cultural changes happened in Spain in the last decades. This increase was enhanced by the CUBG (2006), whose recommendations intend to support women presence on decision-making bodies, and by the implementation of Act 3/2007 of 22 March, in 2007, for Effective Equality between Women and Men (LOIMH, 2007), which frames the regulation of the appointment of men and women on boards of directors in an equitable way. In fact, the LOIMH (2007) recommends Spanish boards of listed companies to reach a gender quota of $40 \%$ by 2015 . Heidrick and Struggles (2014) show that the gender quota of Spanish BDs increased from 9\% in 2011 to $13 \%$ in 2013, which is far from the $40 \%$ recommended by LOIMH (2007). A deep discussion of the presence of female directors on Spanish BDs can be found in De Anca (2008), Campbell and Mínguez-Vera (2010) and Mateos de Cabo et al. (2011), among others.

\section{THEORETICAL BACKGROUND}

Gender diversity on corporate boards has received growing attention within corporate governance (Carrasco and Laffarga, 2007). Most previous research (Rozeff, 1982; Easterbrook, 1984; Jensen, 1986) draws on agency theory to analyse the influence of dividend policy when there are conflicts of interest within organizations, and also to analyse the impact of gender diversity on BDs on dividend payout (Wellalage et al., 2012; Van Pelt, 2013). 
Jensen and Meckling (1976) argued that agency costs may be caused by information asymmetries between shareholders and managers. This gives rise to a conflict of interest between ownership (principal) and the control of the firm (agent), and therefore becomes an agency problem, which makes investors pessimistic about future cash flows being absorbed (Krafft et al., 2013). Managers take daily decisions about the firm's earnings, although they do not always adopt dividend policies which benefit the shareholders' interests. From time to time, managers might prefer dividend policies in line with their personal interests. Grossman and Hart (1980) documented how dividend payout mitigated agency problems in the companies through the reduction of the total amount of free cash flow in hands of the managers. In the same vein, Jensen (1986) showed that the distribution of dividends reduces free cash flow at managers' disposal, prevents unprofitable projects and alleviates agency costs. Hwang et al. (2013) demonstrated that dividend payment reduced the amount of free cash flow, thus reducing minority shareholder rights.

Given that it has an effect on both of their interests, dividend policy is the most significant financial and economic policy for managers and investors. Furthermore, it affects the value and financial and economic capacity of the firm. Dividend payouts reduce the total amount of retained profit and reduce financing with private capital. For this reason, dividend policy depends on companies' profit distribution priorities and investment financing decisions.

The payment of dividends, managerial equity ownership and debt financing are considered effective mechanisms in mitigating agency conflicts of interest within the firm (Bathala and Rao, 1995; Díez et al., 2001). Rozeff (1982) evidenced that dividend payout could be considered as a mechanism to monitor firms. In a similar manner, Easterbrook (1984) reported that dividend payout may mitigate agency problems by increasing the exposure of companies in primary capital markets, since dividend payout enhances the likelihood of issuing new common shares. DeAngelo et al. (2004) showed that companies which pay 
dividends to mitigate agency costs are characterised by low debt capital structures and high cash. Sedzro (2010) examined repurchases and regular and special dividends, and concluded that firms with agency problems increased their regular dividends. Agency theory also suggests that women on corporate boards might make stronger existing control mechanisms over managers and executives, since female directors on BDs increase board independence and are inclined to ask many questions (Carter et al., 2010). Gender heterogeneity among board members improves mutual monitoring and it serves as a "watchdog for shareholder" (Kandel and Lazear, 1992). Thus, women directors on BDs may align the incentives between managers and shareholders through their influence on dividend policies, since they may have high cash flows, and to reduce the problems about free cash flow they may pay high dividends to their shareholders. Moreover, boards with a high percentage of female directors may reduce impediments for dividend pay-out. These views are supported by Knyazeva et al. (2009), who demonstrated that heterogeneous boards were associated with lower cash holdings and higher dividends, and Wellalage et al. (2012), who documented that the presence of female directors on BDs and CEO duality could pay higher dividends to shareholders. In the same line, Byoun et al. (2013) documented that gender diversity on BDs increased the payment of dividends when firms have higher agency conflicts regarding free cash flow, suggesting that females on BDs helped mitigate the free cash flow problem and Van Pelt (2013) reported that the percentage of women on BDs increased payout dividends.

\section{HYPOTHESIS DEVELOPMENT}

\section{Female directors on boards}

Agency theory posits the need to align the interests of shareholders and managers, which may be affected by gender diversity on corporate boards. Gender diversity on BD can help to mitigate agency problems by monitoring and resolving conflicts of interest between managers 
and shareholders (Jurkus et al., 2011), and can increase the amount and quality of information available to the board, improving its ability to advise positions of responsibility on investment decisions. Female directors may monitor management more effectively than male directors (Adams and Ferreira, 2004; Huse and Solberg, 2006), and might act as a control mechanism over managers by supervising board duties, and consequently, agency costs arising from the separation of ownership and management could be reduced (Francoeur et al., 2008; Adams and Ferreira, 2009; Carter et al., 2010) by demanding corporate governance mechanisms such as dividend payment.

Women directors on corporate boards will be more likely to pay dividends, since it may mitigate agency costs and the opportunistic behaviour of management and, as a result, managers being required to seek financing in capital markets. According to Easterbrook (1984), Jurkus et al. (2011) and Byoun et al. (2013), large dividend payments reduce opportunistic conduct and possible over-investment, and improve monitoring of capital markets, reducing agency problems.

In line with stakeholder theory, Hillman et al. (2001) and Webb (2004) argue that gender diversity can help boards to understand and manage stakeholder relationships, which may guarantee the interests of different stakeholder groups. Females on corporate boards might provide a diversity of perspectives and opinions to board discussions, and more responsive policies. As a consequence, gender diversity on BD is assumed to avoid problematic confrontations, which may enhance the demand for control mechanisms such as dividend payments, and accordingly, may defend the interests of all stakeholders. In this vein, female directors on boards consider all legitimate stakeholders in dividend decision-making. Building on cognitive psychology, sociology, economic and management literature, authors such as Webb (2004) and Nielsen and Huse (2010) support the idea that gender diversity on BD provides different perspectives and opinions and leads to greater diversity of knowledge 
and skills (Ruigrok et al., 2006; Lucas-Pérez et al., 2014), which influences democratic decision-making (Eagly et al., 2003; Nielsen and Huse, 2010). Authors such as Parrotta and Smith (2013), Carter et al. (2014) and Harjoto et al. (2014) show that women directors on BD are more risk-averse, more conservative and less overconfident in their decision-making than men (Dowling and Aribi, 2013). Furthermore, female directors on boards and sub-committees may enhance their effectiveness and efficiency since they are presumably, according to Ittonen et al. (2010), highly hard-working and competent. These abilities will make female directors more likely to pay dividends to mitigate agency problems. Consequently, these views seem to support the hypothesis that women directors on boards are more expected to pay dividends. Some previous evidence also supports this thesis (Knyazeva et al., 2009; Ye et al., 2010; Wellalage et al., 2012; Van Pelt, 2013; Harjoto et al., 2014). Accordingly, we predict that female directors on BD may have a positive impact on the demand for corporate governance mechanisms such as dividend payment. Thus, it is expected that, as the percentage of female directors on BD increases, the likelihood of paying dividends will be greater, as female directors on BD will demand more control mechanisms with which to exercise greater supervision and monitoring of both the management team and other members of the BD, making better decisions that positively impact shareholders.

Hence, we posit the following hypothesis:

Hypothesis 1: Dividend policy is positively affected by female directors on boards

\section{Independent female directors on boards}

The presence of independent members on corporate boards is essential to improve the decision-making process and perform the functions of monitoring and supervision (Jensen and Meckling, 1976; Fama and Jensen, 1983), according to agency theory. Thus, independent directors may act as good monitors for shareholders' interest in order to reduce agency 
problems (Bathala and Rao, 1995; Sharma, 2011; Armstrong et al., 2014). In addition, independent directors are more conservative than internal directors and can help to reduce agency costs arising from asymmetric information between shareholders and managers, since they control key decisions of the companies (Ahmed and Duellman, 2007; Wei et al., 2011). Independent directors have strong incentives to issue independent and free judgment relating to management influence (Fama and Jensen, 1983; Weisbach, 1988; Linck et al., 2009).

Independent directors on BD could increase dividend payment since they may serve to reduce agency conflicts between shareholders and management (Rozeff, 1982; Jensen, 1986; Bathala and Rao, 1995). Independent directors can constrain opportunistic behaviours of managers regarding dividend policies, which often are prejudicial for shareholders and benefit managers. Thus, outside directors prefer to pay dividends instead of retaining earnings, because insider directors may mishandling cash retained within the company (Easterbrook, 1984; Wellalage et al., 2012; O'Connor, 2013; Prasanna, 2014).

Stakeholder theory suggests that independent directors on boards can protect the interests of stakeholder better than insiders since they have more perspectives, experience and legal and ethical obligations (Rodriguez-Dominguez et al., 2009), which may increase dividend payout. Based on resource dependency theory, independent directors on boards may affect dividend policy through intangible resources, offering improvement of the communication between the company and relevant external bodies and the reputation, counselling and advice (Pfeffer, 1972; Pfeffer and Salancik, 1978; Hillman et al., 2000). Cognitive psychology, sociology and management literature posits that female directors are more conservative and risk-averse than males (Jianakopolos and Bernasek, 1998; Byrnes et al., 1999; Parrota and Smith, 2013), which may influence corporate decisions and enhance the demands of control mechanisms such as dividend payout. Carter et al. (2003) support the thesis that gender diversity on BD enhances board independence, because directors with more traditional backgrounds do not ask 
the questions that would be asked by directors with ethnicity, cultural background or gender different. Previous research (Adams and Ferreira, 2009; Terjesen et al., 2009; Adams et al., 2010; Srinidhi et al., 2011) also suggests that female directors can monitor managers' and CEOs' behaviour better and more effectively than male directors, through holding more informed discussions, having better communication skills, featuring better independent thinking, and increasing board attendance, among other things, which are critical to checking opportunistic activities and providing better control over management. Similarly, according to Adams and Ferreira (2009), women directors are also more likely to monitor managers' opportunistic behaviours, bring diligence to the board and demand control mechanisms. The assumed benefits of improved independence on corporate boards come from the conviction that independent directors monitor managers better than inside directors (DeFond and Francis, 2005). Therefore, combining independence and the qualities of female directors in comparison to their male counterparts, a positive effect of independent female directors on dividend payment would be expected, because they would have more freedom to support it.

Prior research (Belden et al., 2005; Setia-Atmaja, 2010; Al Shabibi and Ramesh, 2011; Sharma, 2011; Wellalage et al., 2012; Byoun et al., 2013; O'Connor, 2013) reports the positive association between independent directors on $\mathrm{BD}$ and dividend payout. However, to our best knowledge, there are no studies about the impact of independent female directors on dividend policy. Thus, according to the above arguments, we hypothesise that the higher the presence of independent female directors on $\mathrm{BD}$, the greater is the likelihood of paying dividends, as this will allow them to possess more comprehensive control over members of the board (Erhardt et al., 2003), mitigating the conflicts of interest between directors and shareholders (Jurkus et al., 2011). Hence, we posit our hypothesis in the following manner:

Hypothesis 2: Dividend policy is positively affected by independent female directors on boards 


\section{Institutional female directors on boards}

Institutional directors on $\mathrm{BD}$, who represent institutional investors considered shareholders of reference (they may or may not keep business relations in the company where they invest), play an essential role in maximising the benefits of their shareholders. This view has led some institutional investors to give up their traditional passive role, and become actively engaged in management's functions directly, if they are owners of the firms, and indirectly, by buying and selling their stocks (see Montalban and Sakinç, 2013).

According to agency theory, institutional directors may act independently from managers and may act as good monitors to protect the shareholders' interests, mitigating agency problems between shareholders and managers (Brickley et al., 1988; Chung et al., 2002; Abdelsalam et al., 2008; Colpan and Yoshikawa, 2012; Hsu and $\mathrm{Wu}, 2014)$. Institutional investors have more resources and experience in companies and, consequently, they have forceful incentives to control managers' activities (Shleifer and Vishny, 1986; Shleifer and Vishny, 1997; Hsu and $\mathrm{Wu}, 2014)$. In this sense, authors such as Xie et al. (2003), Charitou et al. (2007), Ljungqvist et al. (2007) and Wan-Hussin (2009) show that institutional directors increase corporate transparency, publish unbiased or less-biased information and reduce fraudulent accounting practices, among others. Hence, this perspective exposes a positive relationship between institutional directors on $\mathrm{BD}$ and dividend policy, because they play a complementary role in corporate governance mechanisms. Institutional directors can monitor the company and influence the amount of dividends paid. Chen et al. (2005) report that dividend payout has been used by controlling or institutional shareholders as a way of extracting resources from the firms they control. A large number of previous studies provides evidence that institutional ownership contributes to increased dividend payout (e.g. Han et al., 1999; Short et al., 2002; Farinha, 2003; Abdelsalam et al., 2008; Hovakimian and Li, 2010; Van Pelt, 2013). Furthermore, Faccio and Lasfer (2000), Al-Kuwari (2012) and He et al. 
(2012), among others, demonstrate that institutional directors on BD are more likely to pay dividends, reducing agency problems.

Conversely, Varma (2001) shows that institutional directors are passive, and their role of monitoring managers is ineffective, because they prefer not to actively monitor the managers of a company in which they have invested, due to a conflict of interest arising from their existing business relations with the company (Black, 1992; Kochhar and David, 1996), because of their relatively myopic goals (institutional investors focus on short-term corporate performance) (Coffee, 1991; Bushee, 1998), because of the free-rider problem (Admati et al, 1994) or because they do not have the capability (Taylor, 1990). In this respect, Pound (1993) showed that institutional shareholders empathise with the entrenched managers and vote for them. Consistent with these views, Pound (1988) posited that institutional investors may align themselves with incumbent managers due to strategic alliances or existing relationships between them, and so this leads to a decline in corporate monitoring. Therefore, these views support a negative effect of institutional directors on dividend payment, because institutional investors may cooperate with managers and enjoy the private benefits of control, or preserve their business relations with their firms and, as a consequence, they are less motivated to monitor their governance. Additionally, institutional investors may entrench themselves, and then achieve absolute control of the companies and extract private benefits, negatively impacting corporate monitoring. Consistent with this idea, Van Nuys (1993) demonstrated that institutional directors on BD support managers' decisions and collude with management. Kania and Bacon (2005), Amidu and Abor (2006), Azzam (2010) and Ferreira et al. (2010), among others, showed that institutional ownership impacted negatively on dividend payout. Consistent with agency theory, female directors may act as a mechanism to control managers (Fama and Jensen, 1983; Carter et al., 2003; Adams and Ferreira, 2009), which may mitigate agency costs (Francoeur et al., 2008; Adams and Ferreira, 2009). Prior research (Barber and 
Odan, 2001; Talepsepp, 2010; Dong, 2014) provides evidence that institutional female directors may improve managerial monitoring, because they improve firm performance, which is considered to be a financial mechanism of managerial discipline. Thus, the combination of gender diversity and institutional directors on BD may increase the dividend payout. However, other investigations find that institutional female directors on BD may not have the time or expertise to act as effective monitors, and hence, they could increase agency costs (Pound, 1988; Doukas et al., 2000; McKnight and Weir, 2009). Thus, institutional female directors may use their aptitudes for their private benefit and align themselves with managers, reducing dividend payment (Carson, 2002; Román-Martínez et al., 2012).

Accordingly, based on the above heterogeneous arguments, we posit that institutional female directors may be negative or positively associated with dividend payment, because they may demand more control mechanisms in order to exert more direct control over the management team, reducing information asymmetries and, as a consequence, agency costs (Shleifer and Vishny, 1986; Bathala and Rao, 1995). But the opposite may also be expected, according to prior literature.

Thus, we pose our hypothesis in the following manner:

Hypothesis 3: Dividend policy is positive or negatively affected by institutional female directors on boards

\section{Executive female directors on board}

Prior evidence reports that decisions may be less objective whether executive directors on corporate boards control the decision-making process of management. Likewise, Shivdasami (1993), Yermack (1996) and Armstrong et al. (2014), among others, show that non-executive directors are provided only of a part of information by executive directors with the purpose of preventing stakeholders from having all the information. Executive directors on BD also 
provide knowledge about the inner workings of the firm, because of their relationships within the company, and possess confidential information about the company (Yermack, 1996; Cheng and Courtenay, 2006).

Agency theory posits that in Anglo-Saxon context, where insider directors hold a low level of ownership, dividends are considered as substitute monitoring mechanisms, which may mitigate agency problems. In this vein, dividend payout has been used by companies to reduce agency conflicts between managers and shareholders (Easterbrook, 1984; Jensen, 1986; La Porta et al., 2000). Therefore, in this context large stockholders face a less liquidity for their stocks and may, thus, increase dividend payout (La Porta et al., 2000; Prasanna, 2014). However, in civil law environments there are weak monitoring mechanisms in the management structure because of the dominance of executive directors, as they might have strong incentives to align with management with the purpose of maximizing their wealth to the detriment of shareholders (De Cesari and Ozkan, 2014; Prasanna, 2014). Executive directors on $\mathrm{BD}$ could decrease dividend payment because they do not have the need of using dividend payout as a monitoring mechanism (Maury and Pajuste, 2002; Francis et al., 2014; Van Pelt, 2013; De Cesari and Ozkan, 2014; Prasanna, 2014).

Previous literature demonstrates the negative effect of executive directors on BD on business failure (Hsu and $\mathrm{Wu}, 2014)$, financial disclosure (Cheng and Courtenay, 2006) and firm performance (Cho and Kim, 2007), among others. Furthermore, Ruíz-Barbadillo et al. (2007) found that executive directors on BD increase management dominance over the board, and consequently these directors are less likely to support dividend payout, because these control mechanisms may monitor management actions. Authors such as Zhang (2008), Deshmukh et al. (2010), Banerjee et al. (2013) and Van Pelt (2013) provide evidence of the negative impact on dividend payment of executive directors on BD. 
Sociology, management and cognitive psychology literature argues that female are generally more risk averse and conservative and behave more ethically than males (Byrnes et al., 1999; Parrotta and Smith, 2013; Francis et al., 2014), which may affect corporate decisions and increase the demand for control mechanisms. Hardies et al. (2014) reported that female directors feel that there is more need for planning and are less overconfident than males. Contrary to this evidence, other investigations (Baack et al., 1993; Sarros, 1993; Vilkinas and Cartan, 1993; Petrides and Furnham, 2006) find that no differences exist in the behavior of women and men executives, and the specific skills that they display, such as risk-taking, as well as in the managerial roles performed, are similar. In the same respect, Powell (1990) does not find differences between executive female and male regarding leadership styles and people-oriented behaviour and task-oriented. Morrison et al. (1987) and Lyness and Thompson (1997) found that females and males in executive roles are more similar than different.

Thus, according to previous evidence and arguments, executive female directors are likely to behave the same as male executives, and so both female and male executive directors will align with management, as suggested by the academic literature (Christie and Zimmerman, 1994; Beneish, 2001). Accordingly, we posit that executive female directors on BD are less likely to pay dividends, as evidenced by Francis et al. (2014), who document that female CFOs reduce dividend payout, as this mechanism involves more supervision and control of executive functions and management.

Hence, we posit our hypothesis in the following manner:

Hypothesis 4: Dividend policy is negatively affected by executive female directors on boards 


\section{Shares held by female directors on boards}

When shareholders have greater rights (voting power), according to agency theory, they may make use of this power to affect dividend policy. Authors such as Nielsen (2005), Jiraporn and Ning (2006), Kowalewski et al. (2007) and Adjaoud and Ben-Amar (2010), among others, support this thesis. Prior literature (Hansen and Hill, 1991; Kroll et al., 1997; Stoughton and Zechner, 1998) reports that ownership structure impacts the efficiency of corporate governance and allows for greater outside corporate governance monitoring. Therefore, ownership structure can reduce agency cost by actively monitoring and intervening in major decisions of the company (McConnel and Servaes, 1990).

Jensen and Meckling (1976) and Jensen (1993), based on agency theory, posit that when board directors and managers hold a significant shareholding, management align more closely with shareholders. In this vein, prior research (Crutchley et al., 1999; Ang et al., 2000; Fleming et al., 2005; Lasfer, 2006) reports that management ownership causes a greater alignment of interests between managers and owners, reducing agency problems. Additionally, board directors tend to be more effective monitors of management when they hold a significant stake in the company (Brickley et al., 1988; Brown and Maloney, 1999), and therefore, consistent decisions with maximising stockholders' wealth will be made by these directors (Jensen and Meckling, 1976), since their own wealth will be also maximised. The incentive alignment produced by higher management ownership should lead to larger dividend payout (La Porta et al., 2000; O'Connor, 2013; Florackis et al., 2015). Thus, managerial ownership could be used as an alternative governance mechanism, and the dividend payout could be considered as a management monitoring mechanism (Rozeff, 1982). According to agency theory, female directors on BD may make existing control mechanisms over managers stronger, because female directors increase board independence, and they are inclined to ask many questions (Carter et al., 2010). Therefore, female directors may monitor 
management more effectively than male directors (Adams and Ferreira, 2004; Huse and Solberg, 2006) because their perspectives are more wide-ranging and their decision-making process is more extensive; as a result, this may also lead to a higher demand for control mechanisms such as dividend payment. Stakeholder theory posits that female directors will defend the interests of all stakeholders, avoiding problematic confrontations and providing different opinions and perspectives to board discussions, as well as more responsive policies. These perspectives support the view that shareholding female directors on BD may align the incentives of managers and shareholders through their effect on dividend policy (Byoun et al., 2013; Van Pelt, 2013). Regardless, we predict that the shares held by women directors on BD may have a positive impact on dividend payout, since female ownership is associated with more conservative behaviour and superior performance (Belenzon et al., 2014), which may influence the demand for control mechanism and dividends decisions.

Thus, based on the above arguments, we hypothesise that the proportion of shares held by female directors encourages the demand for control mechanisms such as dividend payout and, therefore, female directors with shares will influence positively on dividend payout.

Hence, we posit the following hypothesis:

Hypothesis 5: Dividend policy is positively affected by the shares held by female directors on boards

\section{EMPIRICAL DESIGN}

\section{Sample}

The sample is drawn from the population of Spanish non-financial firms listed on the Spanish Stock Exchange during 2004-2012. Financial firms are excluded, both because these firms comply with special accounting practices and because listed firms are under special inspection by financial authorities that constrain the role of their BDs. Spanish data is obtained from the 
Sistema de Análisis de Balances Ibéricos (SABI) database, from the web pages of the firms and from the annual reports of corporate governance that all listed firms have been required to disclose since 2003.

An unbalance panel of 894 firm-year observations has been built. The sample represents more than $95 \%$ of the capitalisation of non-financial quoted Spanish firms. However, the estimators of balanced and unbalanced panels provide the same reliability (Arellano, 2003).

\section{Variables}

The dependent variable (DPY) is calculated in three ways: (1) as a dummy variable that takes the value of 1 if the company pays dividends and 0, otherwise (Al-Malkawi, 2008; Al-Najjar and Hussainey, 2009; Byoun et al., 2013); (2) as the ratio between the cash dividends on common stock and the market value of common stock of firms listed on the Madrid Stock Exchange (Fenn and Liang, 2001) and (3) as the logarithm of the total amount of dividends paid per share in the accounting year (Kumar, 2006).

As independent variables, we define the proportion of female directors on the BD as PERWDBD; it is measured as the ratio between the total number of women directors on the $\mathrm{BD}$ and the total number of directors on BDs. The PERIWDBD variable represents the proportion of independent women directors on the $\mathrm{BD}$; this is measured as the ratio between the total number of independent female directors on the BD and the total number of directors on the BD. The PERINSWDBD defines the proportion of institutional female directors; it is measured as the ratio between the total number of institutional women directors on the BD and the total number of directors on the BD. The proportion of executive female directors on the $\mathrm{BD}$ is defined as PEREWDBD; it is measured as the ratio between the total executive women directors on the BD and the total number of directors on the BD. Finally, the variable 
OWNWOMBD represents the proportion of shares held by female directors on the BD; it is measured as the proportion of shares held by women directors.

We control for a number of factors supported by previous evidence (see Rozeff, 1982) that can potentially affect dividend payout. OWNCON measures ownership concentration. Rozeff (1982), Jensen et al. (1992), Gugler and Yurtoglu (2003) and Kumar (2006), among others, provided evidence of the negative impact of ownership concentration on dividend payout. Another control variable used is investment opportunities in line with Ruiz et al. (2008), and we define it as IO. Authors such as Rozeff (1982), Fama and French (2001), Denis and Osobov (2008), Al-Najjar and Hussainey (2009), Setia-Atmaja (2010), Sharma (2011) and O'Connor (2013) demonstrated a negative association between growth opportunities and dividend payout. The ownership of managers is also considered as a control variable; it is defined as OWNMANG. Previous studies (Rozeff, 1982; Fama and French, 2001; Short et al., 2002; Hu and Kumar, 2004; Azzam, 2010) reported a negative relationship between the proportion of shares held by managers and dividend policy. LEV represents the leverage level of the firm. Previous literature (e.g. Díez et al., 2001; Fenn and Liang, 2001; DeAngelo et al., 2004; Ruiz et al., 2008; Setia-Atmaja, 2010; Jirapon et al., 2011; Sharma, 2011; Byoun et al., 2013) has shown that high financial leverage was negatively related to dividend payout. We also control for profitability, which is defined as ROA. Fama and French (2001), Kania and Bacon (2005), Amidu and Abor (2006), Abdelsalam et al. (2008), Denis and Osobov (2008), Al-Najjar and Hussainey (2009), Al Shabibi and Ramesh (2011), Jirapon et al. (2011) and O'Connor (2013) demonstrated that firms with a high return on assets ratio had a greater potential to pay dividends. ROE represents the profitability of stockholders' investments. Previous evidence documented that there was a positive relationship between returns on equity and the dividend payout (Abdelsalam et al., 2008; Ihejirika and Prince, 2012; Malik et al., 2013). 
Previous literature shows a positive association between firm size and the dividend payout (DeAngelo et al., 2004; Denis and Osobov, 2008; Al-Najjar and Hussainey, 2009; Adjaoud and Ben-Amar, 2010; Al Shabibi and Ramesh, 2011; Jirapon et al., 2011; O’Connor, 2013). Thus, we define firm size as FIRMSIZE. Various studies (e.g. Obradovich and Gill, 2012; Mansourinia et al., 2013) reported that board size had a positive impact on paying dividends. We, therefore, define board size as BDSIZE. The proportion of independent directors on BD is also considered as a control variable, denoted as INDP. Authors such as Wellalage et al. (2012) and O'Connor (2013), among others, demonstrated a positive relationship between independent directors on BD and dividend policy. Finally, we also control for institutional directors on BD, variable denoted as INST. Prior evidence is inconclusive since authors such as Abdelsalam et al. (2008), Hovakimian and Li (2010) and Van Pelt (2013) show a positive association between institutional directors on BD and dividend payout, while Kania and Bacon (2005), Amidu and Abor (2006) and Azzam (2010), among others, report a negative relationship. The variables description is shown in Table 1.

\section{Insert Table 1 about here}

To test our hypotheses, we run the following models ${ }^{1}$ :

DPY $_{1 \mathrm{it}}=\alpha+\beta_{1}$ PERWDBD $_{\mathrm{it}}+\beta_{2} \cdot$ PERIWDBD $_{\mathrm{it}}+\beta_{3} \cdot$ PERINSWDBD $_{\mathrm{it}}+\beta_{4} \cdot$ PEREWDBD $_{\mathrm{it}}+$ $\beta_{5}$ OWNWOMBD $_{\text {it }}+\beta_{6} \cdot$ OWNCON $_{\text {it }}+\beta_{7} \cdot$ OWNMANG $_{\text {it }}+\beta_{8} \cdot \mathrm{LEV}_{\text {it }}++\beta_{9} \cdot \mathrm{ROA}_{\mathrm{it}}+\beta_{9} \cdot \mathrm{ROE}_{\mathrm{it}}+$ $\beta_{10} \cdot$ FIRMSIZE $_{i t}+\beta_{11} \cdot$ BDSIZE $_{i t}+\beta_{12} \cdot$ INDP $_{i t}+\beta_{13} \cdot$ INST $_{\text {it }}+\mu_{\mathrm{i}}+\mu_{\mathrm{t}}+\varepsilon_{\mathrm{it}} \quad$ (Model 1) (Logit model)

DPY $_{2}=\alpha+\beta_{1}$ PERWDBD $_{\text {it }}+\beta_{2} \cdot$ PERIWDBD $_{\text {it }}+\beta_{3} \cdot$ PERINSWDBD $_{i t}+\beta_{4} \cdot$ PEREWDBD $_{i t}+$ $\beta_{5}$ OWNWOMBD $_{\text {it }}+\beta_{6} \cdot$ OWNCON $_{\text {it }}+\beta_{7} \cdot$ OWNMANG $_{\text {it }}+\beta_{8} \cdot \mathrm{LEV}_{\mathrm{it}}++\beta_{9} \cdot \mathrm{ROA}_{\mathrm{it}}+\beta_{9} \cdot \mathrm{ROE}_{\mathrm{it}}+$ $\beta_{10} \cdot$ FIRMSIZE $_{\text {it }}+\beta_{11} \cdot$ BDSIZE $_{\text {it }}+\beta_{12} \cdot \operatorname{INDP}_{\text {it }}+\beta_{13} \cdot \mathrm{INST}_{\mathrm{it}}++\mu_{\mathrm{i}}+\mu_{\mathrm{t}}+\varepsilon_{\mathrm{it}} \quad($ Model 2)

DPY $_{i t}=\alpha+\beta_{1}$ PERWDBD $_{i t}+\beta_{2} \cdot$ PERIWDBD $_{\mathrm{it}}+\beta_{3} \cdot$ PERINSWDBD $_{\mathrm{it}}+\beta_{4} \cdot$ PEREWDBD $_{\mathrm{it}}+$ $\beta_{5}$ OWNWOMBD $_{\text {it }}+\beta_{6} \cdot$ OWNCON $_{\text {it }}+\beta_{7} \cdot$ OWNMANG $_{\text {it }}+\beta_{8} \cdot \mathrm{LEV}_{\text {it }}++\beta_{9} \cdot \mathrm{ROA}_{\text {it }}+\beta_{9} \cdot \mathrm{ROE}_{\mathrm{it}}+$ $\beta_{10} \cdot$ FIRMSIZE $_{i t}+\beta_{11} \cdot$ BDSIZE $_{i t}+\beta_{12} \cdot$ INDP $_{i t}+\beta_{13} \cdot$ INST $_{\text {it }}++\mu_{i}+\mu_{\mathrm{t}}+\varepsilon_{\text {it }} \quad($ Model 3)

where $\mu_{\mathrm{i}}$ represents firm fixed effects, $\mu_{\mathrm{t}}$ year fixed effects and $\varepsilon_{\mathrm{it}}$ the error. Firms fixed effects aims at capturing constant and non observable characteristics of the firms that are 
potentially correlated to the dependent variable. We consider year and firm fixed effects to control for year and firm specific effects to dividends.

\section{RESULTS}

\section{Descriptive Statistics}

Table 2 presents the mean value, the standard error and the $25^{\text {th }}, 50^{\text {th }}$ and $75^{\text {th }}$ percentiles of all the variables. As can be seen, $56 \%$ of the Spanish firms decide to pay dividends. In addition, the average ratio between cash dividends on common stock and the market value of common stock of firms is $15.65 \%$, with firms paying $5.68 €$ on average (logarithm of total amount of dividends paid per share in the accounting year). Furthermore, the statistics reveal that $7.8 \%$ of BDs' members are women, consisting of $2.9 \%$ independent female directors, $3.8 \%$ institutional female directors and $0.73 \%$ executive female directors.

The ownership of the firms held by women on BDs is $2.43 \%$, the ownership concentration of the companies is $41.72 \%$, the investment opportunities are $22.42 \%$ and the management ownership is $26.81 \%$. Also, it can be seen that the level of leverage is $60.26 \%$ and the return on assets is, on average, $-2.32 \%$, while the return on equity is $-10.06 \%$. These negative figures are not surprising because some Spanish firms have shown losses for a long period of time.

Finally, the firm size is 13.30 (log of the total assets), the board size, on average, is 10.78 members, the proportion of independent directors on BDs is, on average, $32.50 \%$ and the proportion of institutional directors on BDs is $44.60 \%$.

\section{Insert Table 2 about here}

Table 3 presents the mean differences between the independent variables of Model 1, where the dependent variable DPY1 is a dummy variable which takes the value 1 if the company pays dividends and 0 , otherwise. Two groups have been made up in order to analyse mean differences among independent variables in relation to whether the company pays dividends 
or not. The results in Table 3 show that the mean difference of the variable proportion of independent female directors on BDs is positive and statistically significant at a level of $1 \%$. Thus, these findings show that there is a positive association between the proportion of independent female directors on $\mathrm{BD}$ and the dividend payout. The variable proportion of executive female directors on BD exhibits the predicted sign and it is statistically significant. Therefore, this finding suggests that executive female directors are reluctant to pay dividends. The remainder of independent variables present the expected sign, but they are not statistically significant.

\section{Insert Table 3 about here}

In Table 4 we provide the mean differences between the independent variables of Model 2, where the dependent variable DPY2 represents the dividend payment in relation to the capitalisation. Two groups have been created, according to the median of the dependent variables (which is 6.40). This analysis reports that the variables proportion of independent female directors on BD and the proportion of shares held by female directors are positive and statistically significant. Thus, the proportion of independent female directors and the proportion of shares held by female directors are positively associated with the ratio between cash dividends paid per share and firm capitalisation. The remainder of independent variables offer the predicted sign, but they are not statistically significant.

\section{Insert Table 4 about here}

Table 5 shows the mean difference for the independent variables of Model 3, where the dependent variable DPY3 represents the dividend payment per share in the accounting year. The median of the dependent variable to create the two groups is 7.48 . The analysis of the results reveals that the proportion of independent, institutional and executive female directors on $\mathrm{BD}$ presents the expected sign and is statistically significant. Hence, these findings suggest that a higher proportion of independent female directors on BD is positively associated with 
the dividend payment per share, while the proportion of institutional and executive female directors on $\mathrm{BD}$ is less likely to pay dividends per share in the accounting year. The rest of the independent variables are not statistically significant.

Insert Table 5 about here

\section{Regression Results}

In Table 6 we present the results for the Spearman correlation matrix in order to test for multicollinearity. With the exception of the relation between DPY1, DPY2 and DPY3 (we do not include them together in the regression), the correlation for all the pairs is low (in general below 0.5$)$. Further, the figures of the correlation coefficients are not high enough $(>0.80)$ to cause multicollinearity concerns (see Archambeault and DeZoort, 2001). According to these findings, it can be concluded that these models do not have significant multicollinearity problems.

\section{Insert Table 6 about here}

In Table 7 we show the results of the regression for women directors on BDs. As can be observed, we have built three models. In Model 1 we examine whether firms pay or do not pay dividends; in Model 2 we examine the dividend payment in relation to capitalisation; and in Model 3 we analyse the total amount of dividend payout per share in the accounting year.

\section{Insert Table 7 about here}

According to our predictions - and as can be appreciated in Model 1, where the dependent variable takes the value 1 if the company pays dividends and 0 , otherwise - the proportion of women directors on BDs (PERWDBD) presents the expected sign and is statistically significant. Thus, we cannot reject the first hypothesis: the proportion of women directors on BD increases the probability of dividend payout. Authors such as Knyazeva et al. (2009), Byoun et al. (2013) and Van Pelt (2013) also report a positive association between the proportion of women on $\mathrm{BD}$ and dividend payout. As predicted, the variable proportion of 
institutional female directors on BD (PERINSWDBD) offers a negative sign and is statistically significant. Thus, this finding also supports the third hypothesis, so we can affirm that the proportion of institutional women directors on BD negatively influences decisions regarding paying dividends. Similar evidence was reported by Kania and Bacon (2005), Amidu and Abor (2006), Azzam (2010) and Ferreira et al. (2010), among others. The remaining independent variables: the proportion of independent women directors (PERIWDBD), the proportion of executive women directors (PEREWDBD) and the proportion of shares held by women directors on BD (OWNWOMBD), offer the expected sign, but they are not statistically significant. Hence, we have to reject the second, fourth and fifth hypotheses, and therefore, we cannot provide evidence that the proportion of independent and executive women directors and the proportion of shares held by women directors on BD have an impact on dividend payout. In this sense, Cotter and Sylvester (2003), Chen et al. (2005), Abdelsalam et al. (2008) and Mansourinia et al. (2013), among others, did not find a significant relationship between independent directors and dividend payout. Concerning the non effect of executive directors on the decision to pay dividends, Abor and Fiador (2013) and Mansourinia et al. (2013) provide similar findings, while Zeckhauser and Pound (1990) and Al-Kuwari (2012) also evidenced that controlling shareholders did not have an effect on dividend payout decisions, which is in line with the lack of significance of the variable proportion of shares held by women directors on BDs.

Regarding the control variables, it can be observed that the variables: investment opportunities (IO), management ownership (OWNMANG), leverage (LEV), return on equity (ROE), firm size (FIRMSIZE), board size (BDSIZE) and the proportion of institutional directors on BDs (INST) present the expected sign and are statistically significant. Thus, these findings report that high investment opportunities, high proportions of management ownership and high levels of leverage are negatively associated with decisions relating to 
paying dividends, whereas a company is more likely to pay dividends when return on equity (ROE), firm size, board size and institutional directors on BD increase. The remaining control variables provide the expected sign, but they are not statistically significant.

In Model 2, where the dependent variable is the ratio between cash dividends on common stock and the market value of firms' common stock, the variable proportion of shares held by female directors on BDs (OWNWOMBD) presents a positive sign and is statistically significant. Thus, the fifth hypothesis cannot be rejected, and we can conclude that the proportion of shares held by females on BD increases the ratio between cash dividends and capitalisation. On the other hand, the variable proportion of institutional directors on BDs (PERINSWDBD) presents a negative sign and is statistically significant, as expected. As a result, we cannot reject the third hypothesis. Therefore, this result implies that as the proportion of institutional female directors increases, it is more likely that the ratio between cash dividends and capitalisation will decrease.

In addition, the proportion of female directors (PERWDBD), the proportion of independent directors on BDs (PERIWDBD) and the proportion of executive female directors (PEREWDBD) provide the expected sign; however, they are not statistically significant. Hence, we have to reject the first, second and fourth hypotheses. As a result, we conclude that, as reported in Model 1, the proportion of female directors and the proportion of independent and executive female directors on $\mathrm{BD}$ have no impact on the ratio of dividend policy.

Concerning the control variables, investment opportunities, management ownership, return on equity, firm size and the proportion of institutional directors on BD present the predicted sign and are statistically significant. According to these findings, we can conclude that large companies with high levels of return on equity and institutional directors on $\mathrm{BD}$ are more likely to pay dividends, while firms with high levels of investment opportunities and 
management ownership influence negatively on dividend policy. The remainder of the control variables are not statistically significant.

In Model 3, where the dependent variable is the logarithm of the total amount of dividends paid per share in the accounting year, the results reveal that the proportion of women directors (PERWDBD) and the proportion of shares held by women directors on BDs (OWNWOMBD) present the expected sign and are statistically significant. Thus, we cannot reject the first and fifth hypotheses, and can, therefore, reach the conclusion that the dividend payment will increase when the proportion of female directors and the proportion of shares held by female directors on $\mathrm{BD}$ also increase. As predicted, the variable proportion of institutional female directors on BDs (PERINSWDBD) offers a negative sign and is statistically significant at the $1 \%$ level, which allows us to support the third hypothesis. Thus, these findings show that the proportion of institutional women directors on BDs will reduce the probability of paying dividends. In the same vein, Kania and Bacon (2005) and Amidu and Abor (2006) reported that institutional ownership impacted negatively on dividend payout. Moreover, as can be seen in Models 1 and 2, the other independent variables (PERIWDBD and PEREWDBD) present the expected sign, but they are not statistically significant.

With regards to the control variables, we can appreciate that investment opportunities (IO) and firm size (FIRMSIZE) present the predicted signs and are statistically significant. Therefore, these findings provide evidence that investment opportunities are negatively associated with dividend payout, while firm size will increase the likelihood of paying dividends. The rest of control variables lacks of significance.

We also consider the potential endogeneity between dividend policy and female directors on BDs. In other words, do these directors lead to high dividend payment, or do firms with high dividend payout attract female directors on to their BDs? Although the causality between female directors and dividend payment is more likely to run from directors to dividends, it is 
also possible that the dividend payment could impact on board composition. This issue is approached by running a two-stage least-squares model (2SLS) (Klock et al., 2005). For the sake of brevity, the findings are not reported, which are consistent with our main results, i.e. the estimates of the 2SLS method corroborate the results previously reported.

\section{Analysis Extension}

It is worth remarking that some Spanish listed firms have shown losses during the period of financial crisis, which has been particularly severe in Spain and, as a consequence, it is likely that companies with losses do not pay dividends. Therefore, in the analysis extension we remove from the sample companies which report a negative ROA and ROE in the period of analysis. The results from Table 8 show that firms with profits are more likely to make the decision to pay dividends as the percentage of women directors and independent women directors on BDs increases, while the enhancement in the proportion of institutional and executive women directors on BDs decreases this likelihood. This result suggests that board composition, especially board gender diversity, influences the decision to pay/not to pay dividends, but the shareholding status of female directors on BD does not.

On the other hand, Table 8 also reports that the proportion of independent female directors on BDs and the proportion of female directors are positively associated with the ratio between cash dividends on common stock and market value of common stock of firms, and the logarithm of the total amount of dividends paid per share, respectively, while the proportion of institutional and executive female directors impacts negatively on both measures of dividend policy.

On the whole, these findings suggest that listed firms with profits are more likely to pay dividends when the proportion of female directors and independent female directors on BD increases, while they are less likely to when the proportion of institutional and executive 
women directors on BDs increases. Furthermore, the results also provide evidence of the lack of significance for dividend policy of the shares held by female directors on BDs. Thus, when we only analyse companies with profits, we observe that the proportion of female directors on BDs and institutional female directors on BDs do not change their significant role on dividend policy, while the proportion of independent and executive women directors and the shareholding status of women directors change their role on dividend payment. Concretely, independent and executive female directors have an effect on dividend policy, but the proportion of shares held by female directors does not.

\section{CONCLUSIONS}

Previous literature has analysed the impact of gender diversity on BDs on dividend policy. Following on from these, this study provides insight into the relationship between gender diversity on BDs and dividends policies of firms listed on the Madrid Stock Exchange. Dividend policy is measured in three ways. In Model 1, the dependent variable is a dummy variable which takes the value 1 if the company pays dividends and 0 , otherwise; in Model 2 , the dependent variable is the ratio between cash dividends on common stock and the market value of common stock of firms; and in Model 3, the dependent variable is the logarithm of the total amount of dividend payout per share in the accounting year. We hypothesise that the proportion of female directors on $\mathrm{BD}$, the proportion of independent, institutional and executive directors on $\mathrm{BD}$, and the shares held by women directors on BDs, would affect dividend policy.

Our results, with the whole sample and when only considering firms that exhibit profits, demonstrate that the proportion of female directors on BD positively influences dividend policy, as the proportion of female directors increases the probability of affecting the decision of paying dividends and the payment of dividends per share in the accounting year. These 
results are supported by Ye et al. (2010), who showed that an increase in the proportion of women directors on BDs increases dividend payout.

The proportion of independent women directors on BDs has no impact on dividend policy when the whole sample is analysed, but if we remove from the sample firms with losses, then independent female directors on BDs impact positively on the decision to pay dividends and on the ratio between cash dividends on common stock and the market value of common stock of firms. The proportion of institutional female directors on BD negatively impacts on dividend policy, both for the whole sample and only companies with profits, since there is a negative association between institutional female directors and the decision to pay dividends, as well as the ratio between cash dividends and capitalisation and the payment of dividends per share in the accounting year. This result suggests that institutional female directors on BDs prefer to pay lower dividends, thereby retaining and investing more of their earnings. In line with La Porta et al. (2000), Azzam (2010), Ferreira et al. (2010) and Sáez-Lacave and Gutiérrez-Urtiaga (2014), among others, our findings suggest that in contexts with weak investor protection, as is the case of Spain, the lack of monitoring mechanisms for checking the power of controlling shareholders (institutional shareholders) leads to lower dividend payout. The significant role of institutional directors on BDs and the lack and positive effect of independent directors are supported by these findings, depending on the better or worse performance of the company. The lack of effect of independent female directors on BDs is in line with the evidence suggested in the literature respecting the role of independent directors in European countries (García-Osma and Gill de Albornoz, 2007; García-Meca and SánchezBallesta, 2009; Lorca et al., 2011), which may be because institutional women directors perform the role of independent female directors (substitute effect between them) or, as Abdelasam et al. (2008) and Mansourinia et al. (2013) reported, because independent female directors on BDs cannot influence the dividend policy decisions of executive directors and 
managers. On the other hand, the positive impact of independent female directors on dividend policy when firms exhibit profits may be due to the fact that they can constrain the opportunism of managers regarding dividends policies, which often benefit them and other stakeholders in the detriment of stockholders, and because independent female directors possess more comprehensive control over members of the BD (Erhardt et al., 2003), which could also reduce conflicts of interest between shareholders and managers (Jurkus et al., 2011).

The proportion of executive women directors on boards has no effect on the dividend payout when analysing the whole sample. This finding is supported by Mansourinia et al. (2013), suggesting that executive female directors have more firm-specific information, and that rather than paying dividends, they prefer instead to have greater control of cash to invest in their firms' projects, leading to higher returns. This argument is consistent with Jensen (1986) and Crifo and Forget (2013), who argue that managers have incentives to waste organizational resources in their own benefit when they hold extra cash flow, rather than use this excess of cash flow to pay dividends to shareholders. Nevertheless, when companies with losses are excluded from the sample, executive female directors impact negatively on dividend policy of firms, as Van Pelt (2013) reports, suggesting that they are expected to pay fewer dividends in order to retain more earnings and, therefore, agency costs will be mitigated.

The proportion of shares held by female directors on BD has no effect on the decision of paying dividends or not, but it raises the ratio between cash dividends and capitalisation and the amount of dividends paid by share in the accounting year. The findings suggest that shareholders whose rights are stronger may pressure managers to increase the payment of dividends, using the power of the rights (La Porta, et al., 2000; Brockman and Unlu, 2009; Adjaoud and Ben-Amar, 2010). Conversely, the shareholding status of female directors on BD does not drive any impact on dividend policy, when the sample only consists of firms 
with profits, suggesting that female directors with shares prefer not to receive dividends since this retains earnings which could be invested in the company, enhancing firm performance.

The limitations of this study are as follows. Firstly, based on theory and previous empirical research, we have addressed as many factors as possible, but it is likely that there are no known features that may influence the dependent variables of this study. To know whether all significant factors have been controlled for is conditioned by empirical and theoretical limitations. Secondly, the study is based on the Spanish Stock Exchange for the period 20042012 and, therefore, the findings provided should not to be extrapolated to other periods or countries.

This investigation could give rise to future lines of research. Firstly, it would add value to analyse the effect of gender diversity on BDs on the shares repurchased. Secondly, it would be interesting to analyse the association between gender diversity on BDs and dividends in the context of small and medium sized enterprises (SMEs).

\section{Notes}

${ }^{1}$ Fix effects have been used in the three models because Hausman test has not allowed using random effects.

\section{Acknowledgments}

This paper has received financial support from the Spanish Ministry of Science and Innovation under project ECO2011-29144-C03-02 and FEDER. We would like also to thank the two anonymous referees for their helpful comments.

\section{REFERENCES}

Abdelsalam, O., A. El-Masry, and S. Elsegini (2008), 'Board composition, ownership structure and dividend policies in an emerging market: Further evidence from CASE 50,' Managerial Finance, 34(12), 953-964.

Abor, J. and V. Fiador (2013), 'Does corporate governance explain dividend policy in SubSaharan Africa?' International Journal of Law and Management, 55(3), 201-225.

Act 3/2007 of 22 March, for Effective Equality between Women and Men (LOIMH). (BOE $n$. 71 de 23/3/2007).

Adams, R. and D. Ferreira (2003), 'Diversity and incentives: evidence from corporate boards,' Unpublished working paper, University of Stockholm.

Adams, R. B. and D. Ferreira D. (2004), 'Gender diversity in the boardroom,' European Corporate Governance Institute, Finance Working paper, 57, 1-30. 
Adams, R. B. and D. Ferreira (2009), 'Women in the Boardroom and their impact of governance and performance,' Journal of Financial Economics, 94(2), 291-309.

Adams, R., B. Hermalin and M. Weisbach (2010), 'The role of boards of directors in corporate governance: A conceptual framework and survey,' Journal of Economic Literature, 48, 58-107.

Adjaoud, F. and W. Ben-Amar (2010), 'Corporate governance and dividend policy: shareholders' protection or expropriation?' Journal of Business Finance \& Accounting, 37(5-6), 648-667.

Admati, A. R., P. Pfleiderer and J. Zechner (1994), 'Large shareholder activism, risk sharing, and financial market equilibrium,' Journal of Political Economy, 102(6), 1097-1130.

Ahmed, H. and A. Y. Javid (2009), 'Dynamics and determinants of dividend policy in Pakistan (evidence from Karachi stock exchange non-financial listed firms),' International Research Journal of Finance and Economics, 25, 148-171.

Al Shabibi, B. K. and G. Ramesh (2011), 'An empirical study on the Determinants of Dividend Policy in the UK,' International Research Journal of Finance and Economics, 80, 105-120.

Aldama Report (2003), Informe de la Comisión Especial para el Fomento de la transparencia y la seguridad en los Mercados Financieros y en las Sociedades Cotizadas. Madrid: Ministerio de Economía y Hacienda.

Al-Kuwari, D. (2012), 'Are Large Shareholders Conducting Influential Monitoring in Emerging Markets? An Investigation into the Impact of Large Shareholders on Dividend Decisions: The Case of Kuwait,' Research in World Economy, 3(2), 52-67.

Al-Malkawi, H. A. N. (2008), 'Factors influencing corporate dividend decision: evidence from Jordanian panel data,' International Journal of Business, 13(2), 177-195.

Al-Najjar, B. and K. Hussainey (2009), 'The association between dividend payout and outside directorships,' Journal of Applied Accounting Research, 10(1), 4-19.

Amidu, M. and J. Abor (2006), 'Determinants of dividend payout ratios in Ghana', The Journal of Risk Finance, 7(2), 136-145.

Amihud, Y. and M. Murgia (1997), 'Dividends, taxes, and signaling: evidence from Germany,' The Journal of Finance, 52(1), 397-408.

Ang, J. S., R. A. Cole and W. Lin (2000), 'Agency cost and ownership structure,' Journal of Finance, 55(1), 81-106.

Archambeault, D. and F. T. DeZoort (2001), 'Auditor opinion shopping and the audit committee: An analysis of suspicious auditor switches,' International Journal of Auditing, 5(1), 33-52.

Armstrong, C. S., J. E. Core and W. R. Guay (2014), 'Do independent directors cause improvements in firm transparency?' Journal of Financial Economics, 113(3), 383-403.

Arellano, M. (2003), Panel data econometrics. Oxford: Oxford University Press. London.

Azzam, I. (2010), 'The impact of institutional ownership and dividend policy on stock returns and volatility: Evidence from Egypt,' International Journal of Business, 15(4), 443-458.

Baack, J., N. Carr-Ruffino and M. Pelletier (1993), 'Making it to the top: specific leadership skills,' Women in Management Review, 8(2), 17-23

Barber, B. M. and T. Odean (2001), 'Boys will be boys: gender, overconfidence, and common stock investment,' Quarterly Journal of Economics, 116(1), 261-292.

Banerjee, S., M. Humphery-Jenner and V. Nanda (2013), 'CEO Overconfidence and Share Repurchases,' Unpublished working paper, 26th Australasian Finance and Banking Conference 2013, UNSW Australian School of Business Research Paper No. 2013 BFIN 04, Available at: http://ssrn.com/abstract $=2267218$. 
Bathala, C. T. and R. P. Rao (1995), 'The determinants of board composition: An agency theory perspective,' Managerial and Decision Economics, 16(1), 59-69.

Belden, S., T. Fister and B. O. B. Knapp (2005), 'Dividends and directors: do outsiders reduce agency costs?' Business and Society Review, 110(2), 171-180.

Belenzon, S., A. Patacconi and R. Zarutskie (2014), 'Married to the Firm? A Large-Scale Investigation of the Social Context of Ownership,' A Large-Scale Investigation of the Social Context of Ownership, Unpublished working paper, Available at: http://ssrn.com/abstract=2476944.

Beneish, M. D. (2001), 'Earnings management: A perspective,' Managerial Finance, 27(12), 3-17.

Bhattacharya. S. (1979), 'Imperfect information, dividend policy and the 'bird in the hand fallacy', Bell Journal of Economics, 10(1), 259-270.

Black, B. S. (1992), 'Institutional investors and corporate governance: The case for institutional voice,' Journal of Applied Corporate Finance, 5(3), 19-32.

Brickley, J. A., R. C. Lease and C. W. Smith (1988), 'Ownership structure and voting on antitakeover amendments,' Journal of Financial Economics, 20, 267-291.

Brockman, P. and E. Unlu (2009), 'Dividend policy, creditor rights, and the agency costs of debt,' Journal of Financial Economics, 92(2), 276-299.

Brown, W. O. and M. T. Maloney (1999), 'Exit, voice, and the role of corporate directors: Evidence from acquisition performance,' Unpublished working paper, Available at: http://ssrn.com/abstract $=160308$

Burgess, Z. and P. Tharenou (2002), 'Women board directors: Characteristics of the few,' Journal of Business Ethics, 37(1), 39-49.

Bushee, B. J. (1998), 'The influence of institutional investors on myopic R\&D investment behaviour,' The Accounting Review, 73(3) 305-333.

Byoun, S., K. Chang and Y. Kim (2013), 'Does Corporate Board Diversity Affect Corporate Payout Policy?' Unpublished working paper, Baylor University, Available at: http://ssrn.com/abstract=1786510.

Byrnes, J., D. Miller and W. Schafer (1999), 'Gender Differences in Risk Taking: A Metaanalysis,' Psychological Bulletin, 125(3): 367-383.

Campbell, K. and A. Mínguez-Vera (2008), 'Gender diversity in the Boardroom and firm financial performance,' Journal of Business Ethics, 83(3), 435-451.

Campbell, K. and Mínguez-Vera, A. (2010). 'Female board appointments and firm valuation: Short and long-term effects,' Journal of Management \& Governance, 14(1), 37-59.

Carrasco, A. and J. Laffarga (2007), 'La diversidad en el código de buen gobierno. Conocimiento, Innovación y Emprendedores; Camino al Futuro,' Pecvina, 5, 1-25.

Carson, E. (2002), 'Factors associated with the development of Board Sub-Committees,' Corporate Governance: An International Review, 10(1), 4-18.

Carter, D. A., B. J. Simkins and W. G. Simpson (2003), 'Corporate governance, board diversity, and firm value,' Financial Review, 38(1), 33-53.

Carter, D. A., F. D'Souza, B. J. Simkins and W. G. Simpson (2010), 'The gender and ethnic diversity of US Boards and Board Committees and firm financial performance,' Corporate Governance: An International Review, 18(5): 396-414.

Carter, M. E., F. Franco and M. Gine (2014), 'Executive Gender Pay Gaps: The Roles of Board Diversity and Female Risk Aversion,' Unpublished working paper, Available at: http://ssrn.com/abstract=2503883

Catalyst (2004), The Bottom Line: Connecting corporate performance and gender diversity. Catalyst: New York, NY. 
Charitou, A., N. Lambertides and L. Trigeorgis (2007), 'Earnings behaviour of financially distressed firms: the role of institutional ownership,'Abacus, 43(3), 271-296.

Chen, Z., Y. L. Cheung, A. Stouraitis and A. W. Wong (2005), 'Ownership concentration, firm performance, and dividend policy in Hong Kong,' Pacific-Basin Finance Journal, 13(4), 431-449.

Cheng, E. C. M. and S. M. Courtenay (2006), 'Board composition, regulatory regime and voluntary disclosure,' The International Journal of Accounting, 41(3), 262-289.

Cho, D. S. and J. Kim (2007), 'Outside directors, ownership structure and firm profitability in Korea,' Corporate Governance: An International Review, 15(2), 239-250.

Christie, A. A. and J. L. Zimmerman (1994), 'Efficient and opportunistic choices of accounting procedures: Corporate control contests,' The Accounting Review, 69(4), 539566.

Chung, R., M. Firth and J. B. Kim (2002), 'Institutional Monitoring and Opportunistic Earnings Management,' Journal of Corporate Finance, 8(1), 29-48.

Coffee, J. C. (1991), 'Liquidity versus control: The institutional investor as corporate monitor,' Columbia Law Review, 91(6), 1277-1368

Colpan, A. M. and T. Yoshikawa (2012), 'Performance sensitivity of executive pay: the role of foreign investors and affiliated directors in Japan,' Corporate Governance: An international review, 20(6), 547-561.

Cotter, J. and M. Silvester (2003), 'Board and monitoring committee independence,' Abacus, 39(2), 211-232.

Crifo, P. and V. D. Forget (2013), 'Think global, invest responsible: Why the private equity industry goes green,' Journal of Business Ethics, 116(1), 21-48.

Crutchley, C. E., M. R. H. Jensen, J. S. Jahera and J. E. Raymond (1999), 'Agency problems and the simultaneity of financial decision making. The role of institutional ownership,' International Review of Financial Analysis, 8(2), 177-197.

De Anca, C. (2008), 'Women on corporate boards of directors in Spanish listed companies,' Women on corporate boards of directors: International research and practice, 79-87.

De Cesari, A. and N. Ozkan (2014), 'Executive Incentives and Payout Policy: Empirical Evidence from Europe,' Journal of Banking \& Finance, 55, 70-91

DeAngelo, H., L. DeAngelo and D. J. Skinner (2004), 'Are dividends disappearing? Dividend concentration and the consolidation of earnings,' Journal of Financial Economics, 72(3), 425-456.

DeFond, M. L. and J. R. Francis (2005), 'Audit research after sarbanes-oxley,' Auditing: A Journal of Practice \& Theory, 24(s-1), 5-30.

Mateos De Cabo, R. M., R. Gimeno and L. Escot (2011), 'Disentangling discrimination on Spanish boards of directors,' Corporate Governance: An International Review, 19(1), 77 95.

Denis, D. J. and I. Osobov (2008), 'Why do firms pay dividends? International evidence on the determinants of dividend policy,' Journal of Financial Economics, 89(1), 62-82.

Deshmukh, S., A. Goel and K. Howe (2010), 'CEO overconfidence and dividend policy,' Journal of Financial Intermediation, 22(3), 440-463.

Díez de Foronda, Ó. L. and J. M. D. Esteban (2001), 'La política de dividendos de las empresas españolas: un ajuste parcial al objetivo de reparto,' Cuadernos de Estudios Empresariales, 11, 141-159.

Dong, H. (2014), 'Essays on Mutual Fund Strategies and Investor Characteristics,'. Doctoral dissertion, Universidad Carlos III: Madrid.

Doukas, J. A., C. Kim and C. Pantzalis (2000), 'Security analysis, agency costs, and company characteristics,' Financial Analysts Journal, 56(6), 54-63. 
Dowling, M. and Z. A. Aribi (2013), 'Female directors and UK company acquisitiveness,' International Review of Financial Analysis, 29, 79-86.

Eagly, A. H. and L. L Carli (2003), 'The female leadership advantage: An evaluation of the evidence,' The Leadership Quarterly, 14(6), 807-834

Easterbrook, F. H. (1984), 'Two agency-cost explanations of dividends,' The American Economic Review, 74(4), 650-659.

Erhardt, N., J. Werbel and C. Shrader (2003), 'Board of director diversity and firm financial performance,' Corporate Governance: An International Review, 11(2), 102-110.

Erol, I. and D. Tirtiroglu (2011), 'Concentrated ownership, no dividend payout requirement and capital structure of REITs: Evidence from Turkey,' The Journal of Real Estate Finance and Economics, 43(1-2), 174-204.

Faccio, M. and M. A. Lasfer (2000), 'Do occupational pension funds monitor companies in which they hold large stakes?' Journal of Corporate Finance, 6(1), 71-110.

Fama, E. F. and K. R. French (2001), 'Disappearing dividends: changing firm characteristics or lower propensity to pay?' Journal of Financial Economics, 60(1), 3-43.

Fama, E. F. and M. C. Jensen (1983), 'Separation of ownership and control,' Journal of Law and Economics, 26(2), 301-325.

Farinha, J. (2003), 'Dividend policy, corporate governance and the managerial entrenchment hypothesis: an empirical analysis,' Journal of Business Finance \& Accounting, 30(9-10), 1173-1209.

Farrel, K. and P. Hersch (2005), 'Additions to corporate boards: the effect of gender,' Journal of Corporate Finance, 11(1), 85-106.

Fenn, G. W. and N. Liang (2001), 'Corporate payout policy and managerial stock incentives,' Journal of Financial Economics, 60(1), 45-72.

Ferreira, M. A., M. Massa and P. Matos (2010), 'Dividend clienteles around the world: Evidence from institutional holdings,' Marshall School of Business Working Paper No FBE, Available at: http://ssrn.com/abstract $=1447573$

Fleming, G., R. Heaney and R. McCosker (2005), 'Agency costs and ownership structure in Australia,' Pacific-Basin Finance Journal, 13(1), 29-52.

Flint, A., A. Tan and G. Tian (2010), 'Predicting future earnings growth: a test of the dividend payout ratio in the Australian market,' The International Journal of Business and Finance Research, 4(2), 43-58.

Florackis, C., A. Kanas and A. Kostakis (2015), 'Dividend policy, managerial ownership and debt financing: A non-parametric perspective,' European Journal of Operational Research, 241(3), 783-795.

Francis, B., I. Hasan, J. C. Park and Q. Wu (2014), 'Gender differences in financial reporting decision making: Evidence from accounting conservatism,' Contemporary Accounting Research, Available at: http://onlinelibrary.wiley.com/doi/10.1111/1911-3846.12098/pdf

Francoeur, C., R. Labelle and B. Sinclair-Desgnané (2008), 'Gender diversity in Corporate Governance and top management,' Journal of Business Ethics, 81(1), 83-95.

García-Meca, E. and J. P. Sánchez-Ballesta (2009), 'Corporate Governance and Earnings Management: A Meta-Analysis,' Corporate Governance: An International Review, 17(5), 594-610.

García-Osma, B. and B. Gill de Albornoz-Noguer (2007), 'The Effect of the Board Composition and its Monitoring Committees on Earnings Management: evidence from Spain,' Corporate Governance: An International Review, 15(6), 1413-1428.

Grossman, S. J. and O. D. Hart (1980), 'Takeover bids, the free-rider problem, and the theory of the corporation,' The Bell Journal of Economics, 11(1), 42-64. 
Gugler, K. and B. B. Yurtoglu (2003), 'Corporate governance and dividend pay-out policy in Germany,' European Economic Review, 47(4), 731-758.

Gulzar, M. A. and Z. Wang (2011), 'Corporate governance characteristics and earnings management: Empirical evidence from Chinese listed firms,' International Journal of Accounting and Financial Reporting, 1(1): 133-151.

Gupta, A. and A. Parua (2012), 'Payout Policy on Agency Perspective: An empirical test in Indian Context,' Journal of Management, 9(2), 109-120.

Han, K. C., S. H. Lee and D. Y. Suk (1999), 'Institutional shareholders and dividends,' Journal of financial and Strategic Decisions, 12(1), 53-62.

Hansen, G. and C. W. L. Hill (1991), 'Are institutional investors myopic? A time-series study of four technology-driven industries,' Strategic Management Journal, 12(1), 1-16.

Hardies, K., A. Jorissen and P. Maneemai (2014), 'On the Presence and Absence of CEO Gender Effects on Management Control Choices: An Empirical Investigation,' Unpublished working paper, Available at: http://ssrn.com/abstract=2496613

Harjoto, M.A., I. Laksmana and Y.W. Yang (2014), 'Board Diversity and Corporate Risk Taking', Unpublished working paper, Available at: http://ssrn.com/abstract=2412634.

He, T. T., W. X. B. Li and G. Y. N. Tang (2012), 'Dividends Behaviour in State- Versus Family-Controlled Firms: Evidence from Hong Kong,' Journal of Business Ethics, 110(1), 97-112.

Heidrick and Struggles (2014), Towards dynamics governance 2014. European corporate governance report. Chicago, IL: Heidrick \& Struggles.

Hillman, A. J., A. A Cannella and R. L. Paetzold (2000), 'The resource dependence role of corporate directors: Strategic adaptation of board composition in response to environmental change,' Journal of Management studies, 37(2): 235-256.

Hillman, A. J., G. D. Keim and R. A. Luce (2001),' Board composition and stakeholder performance: Do stakeholder directors make a difference?' Business \& Society, 40(3), 295-314.

Hovakimian, A. and G. Li (2010), 'Shareholder investment horizons and payout policy,' Unpublished working paper, Baruch College, Available at:http://ssrn.com/abstract $=1571757$

Hsu, H. H. and Y. H. Wu (2014), 'Board composition, grey directors and corporate failure in the UK,' The British Accounting Review, 46(3), 215-227.

$\mathrm{Hu}, \mathrm{A}$. and P. Kumar (2004), 'Managerial entrenchment and payout policy,' Journal of Financial and Quantitative Analysis, 39(4), 759-790.

Huse, M. and A. G. Solberg (2006), 'Gender-related boardroom dynamics: How Scandinavian women make and can make contributions on corporate boards,' Women in Management Review, 21(2), 113-130.

Huse, M., S. Nielsen and I. M. Hagen (2009), 'Women and employee-elected board members, and their contributions to board control tasks,' Journal of Business Ethics, 89(4): 581-597.

Hwang, L. S., H. Kim, K. Park and R. S. Park (2013), 'Corporate Governance and Payout Policy: Evidence from Korean Business Groups,' Pacific-Basin Finance Journal, 24, 179 198.

Ihejirika, P. and N. Prince. (2012), 'An empirical analysis of the propensity to pay or not to pay dividends: A test of the life cycle theory with Nigerian data', Arabian Journal of Business and Management Review, 1(12), 74-87.

INE (2015), 'Instituto Nacional de Estadística,'Available at: http://www.ine.es/ Consulted: February 20, 2015. 
Ittonen, K., J. Miettinen and S. Vähämaa (2010), 'Does female representation in audit committees affect audit fees?' Quarterly Journal of Finance and Accounting, 49(3-4), 113-139.

Jensen, M. C. (1986), 'Agency costs of free cash flow, corporate finance, and takeovers,' The American Economic Review, 76(2), 323-329.

Jensen, M. C. (1993), 'The modern industrial revolution, exit, and the failure of internal control systems,' Journal of Finance, 48(3), 831-880

Jensen, M. C. and W. H. Meckling (1976), 'Theory of the firm: Managerial behavior, agency costs and ownership structure,' Journal of Financial Economics, 3(4), 305-360.

Jensen, G. R., D. P.Solberg and T. S. Zorn (1992), 'Simultaneous determination of insider ownership, debt, and dividend policies,' Journal of Financial and Quantitative Analysis, 27(2), 247-263.

Jianakoplos, N. and A. Bernasek (1998), 'Are Women More Risk Averse?' Economic Inquiry, 36(4), 620-630.

Jiraporn, P. and Y. Ning (2006), 'Dividend policy, shareholder rights, and corporate governance,' Journal of Applied Finance, 16(2), 24

Jiraporn, P., J. C. Kim and Y. S. Kim (2011), 'Dividend payouts and corporate governance quality: An empirical investigation,' Financial Review, 46(2), 251-279.

Jurkus, A. F., J. C. Park and L. S. Woodard (2011), 'Women in top management and agency costs,' Journal of Business Research, 64(2), 180-186.

Kandel, E. and E. P. Lazear (1992), 'Peer pressures and partnerships,' Journal of Political Economy, 100(4), 801-817.

Kania, S. L. and F. W. Bacon (2005), 'What factors motivate the corporate dividend decision,' ASBBS E-Journal, 1(1), 97-107.

Klock, M. S., S. A. Mansi and W. F. Maxwell (2005), 'Does corporate governance matter to bondholders?' Journal of Financial and Quantitative Analysis, 40(4), 693-719.

Knyazeva, A., D. Knyazeva and C. Raheja (2009), 'The benefits of focus vs. heterogeneity: An analysis of corporate boards,' Unpublished working paper, University of Rochester.

Kochhar, R. and P. David (1996), 'Institutional investors and firm innovation: A test of competing hypotheses,' Strategic Management Journal, 17(1), 73-84.

Kowalewski, O., I. Stetsyuk and O. Talavera (2007), 'Corporate Governance and Dividend Policy in Poland,' Unpublished working paper, German Institute for Economic Research.

Krafft, J., Y. Qu, F. Quatraro and J-L. Ravix (2013), 'Corporate governance, value and performance of firms: new empirical results on convergence from a large international database,' Industrial and Corporate Change, 23(2), 361-397.

Krishnan, G. V. and D. Park (2005), 'A few good women - on top management teams,' Journal of Business Research, 58(12), 1712-1720.

Kroll, M., P. Wright, L. Toombs and H. Leavell (1997), 'Form of control: a critical determinant of acquisition performance and CEO rewards,' Strategic Management Journal, 18(2), 85-96.

Kumar, J. (2006), 'Corporate governance and dividend payout in India,' Journal of Emerging Market Finance, 5(1), 15-58.

La Porta, R., F. Lopez-de-Silanes, A. Shleifer and R. Vishny (2000), 'Investor protection and corporate governance,' Journal of Financial Economics, 58(1), 3-27.

Lasfer, M. A. (2006), 'The interrelationship between managerial ownership and Board structure,' Journal of Business Finance and Accounting, 33(7-8), 1006-1033.

Linck, J. S., J. M. Netter and T. Yang (2009), 'The effects and unintended consequences of the Sarbanes-Oxley Act on the supply and demand for directors,' Review of Financial Studies, 22(8), 3287-3328. 
Ljungqvist, A., Marston, F., Starks, L. T., Wei, K. D. and Yan, H. (2007), 'Conflicts of interest in sell-side research and the moderating role of institutional investors,' Journal of Financial Economics, 85(2), 420-456.

Lorca, C., J. Sánchez-Ballesta and E. García-Meca (2011), 'Board effectiveness and cost of debt,' Journal of Business Ethics, 100(4), 613-631.

Lucas-Pérez, M. E., A. Mínguez-Vera, J. S. Baixauli-Soler, J. F. Martín-Ugedo and G. Sánchez-Marín (2014), 'Women on the board and managers' pay: Evidence from Spain,' Journal of Business Ethics, 129(2), 1-16.

Lyness, K. S. and D. E. Thompson (1997), 'Above the glass ceiling? A comparison of matched samples of female and male executives,' Journal of Applied Psychology, 82(3), 359-375.

Malik, F., S. Gul, M. T. Khan and S. U. Rehman (2013), 'Factors Influencing Corporate Dividend Payout Decisions of Financial and Non-Financial Firms,' Research Journal of Finance and Accounting, 4(1), 35-46.

Mansourinia, E., M. Emamgholipour, E. A. Rekabdarkolaei and M. Hozoori (2013), 'The Effect of Board Size, Board Independence and CEO Duality on Dividend Policy of Companies: Evidence from Tehran Stock Exchange,' International Journal of Economy, Management and Social Sciences, 2(6), 237-241.

Maury, C. B. and A. Pajuste (2002), 'Controlling shareholders, agency problems, and dividend policy in Finland,' LTA, 1(2), 15-45.

McKnight, P. J. and C. Weir (2009), 'Agency costs, corporate governance mechanisms and ownership structure in large UK publicly quoted companies: A panel data analysis,' The Quarterly Review of Economics and Finance, 49(2), 139-158.

McConnell, J. J. and H. Servaes (1990), 'Additional evidence on equity ownership and corporate value,' Journal of Financial Economics, 27(2), 595-612.

Montalban, M. and M. Sakinç (2013),'Financialization and productive models in the pharmaceutical industry,' Industrial and Corporate Change, 22(4), 981-1030.

Morrison, A. M., R. P. White and E. Van Velsor (1987), Breaking the Glass Ceiling: Can Women Reach the Top of America's Largest Corporations? Reading, MA: AddisonWesley.

Nielsen, A. (2005), 'Corporate governance, Leverage and dividend policy,' Unpublished working paper, In EFA 2006 Zurich Meetings.

Nielsen, S. and M. Huse (2010), 'The contribution of women on Boards of Directors: Going beyond the Surface,' Corporate Governance: An International Review, 18(2): 136-148.

Obradovich, J. and A. Gill (2013), 'Coporate Governance, Institutional Ownership, and the Decision to Pay the Amount of Dividends: Evidence from USA,' International Research Journal of Finance and Economics, 97, 60-71.

O'Connor, T. (2013), 'Dividend payout and corporate governance in emerging markets: which governance provisions matter?' International Journal of Corporate Governance, 4(2), 181-207.

Olivence Report (1998), El buen Gobierno de las Sociedades. Madrid: Ministerio de Economía y Hacienda, Madrid.

Parrotta, P. and N. Smith (2013), 'Female-Led Firms: Performance and Risk Attitudes,' Unpublished working paper, Available at: http://ssrn.com/abstract=2329083

Petrides, K. V. and A. Furnham (2006), 'The role of trait emotional intelligence in a genderspecific model of organizational variables,' Journal of Applied Social Psychology, 36(2), 552-569.

Pfeffer, J. (1972), 'Size and composition of corporate boards of directors: The organization and its environment,' Administrative Science Quarterly, 17(2), 218-228. 
Pfeffer, J. and G. R. Salancik (1978), The external control of organizations: A resource dependence perspective. New York: Harper \& Row.

Pound, J. (1988), 'Proxy contests and the efficiency of shareholder oversight,' Journal of Financial Economics, 20, 237-265.

Pound, J. (1993), 'Rise of the Political Model of Corporate Governance and Corporate Control', New York University Law Review, 68(3), 1003-1071.

Powell, G. N. (1990), 'One more time: do female and male managers differ?' Academy of Management Executive, 4(3), 68-75.

Prasanna, P. K. (2014), 'Firm-level governance quality and dividend decisions: evidence from India,' International Journal of Corporate Governance, 5(3), 197-222.

Qi, B. and G. Tian (2012), 'The impact of Audit Committees' personal characteristics on earnings management: Evidence from China,' Journal of Applied Business Research, 28(6), 1331-1343.

Rakotomavo, M. T. (2010), 'Payout and asymmetric information,' Applied Economics Letters, 17(13), 1299-1304.

Rodriguez-Dominguez, L., I. Gallego-Alvarez and I. M. Garcia-Sanchez (2009), 'Corporate governance and codes of ethics,' Journal of Business Ethics, 90(2), 187-202.

Rogelberg, S. G. and S. M. Rumery (1996), 'Gender diversity, team decision quality, time on task, and interpersonal cohesion,' Small Group Research, 27(1), 79-90.

Román-Martínez, I., E. Argente-Linares, M. E. Gómez-Miranda and L. Rodríguez-Ariza (2012), 'Voluntary formation of audit committees in non-listed companies: The case of Morocco,' African Journal of Business Management, 6(29), 8757-8765.

Rose, C. (2007), 'Does female board representation influence firm performance? The Danish evidence,' Corporate Governance: An International Review, 15(2), 404-413.

Ross, S. (1977), 'The determination of financial structure: the incentive-signalling approach,' Bell Journal of Economics, 8(1), 23-40.

Rozeff, M. S. (1982), 'Growth, Beta and Agency Costs as Determinants of Dividend Payout Ratios,' Journal of Financial Research, 5(3), 249-259.

Ruigrok, W., S. Peck, S. Tacheva, P. Greve, and Y. Hu (2006), 'The determinants and effects of Board Nomination Committees,' Journal of Management and Governance, 10(2), 119148.

Ruiz, M. V., D. J. Santana, I. Aguilar and N. L. Díaz (2008), 'Propiedad institucional y dividendos,' Revista Europea de Dirección y Economía de la Empresa, 17(3), 93-110.

Ruíz-Barbadillo, E., E. Biedma-López and N. Gómez-Aguilar (2007), 'Managerial dominance and Audit Committee independence in Spanish Corporate Governance,' Journal of Management \& Governance, 11(4), 331-352.

Sáez Lacave, M. I., and M. Gutiérrez Urtiaga (2014), 'Dividend Policy with Controlling Shareholders,' Theoretical Inquiries in Law, 16(1), 107-130.

Said, H. B. (2013), 'Impact of Ownership Structure on Debt Equity Ratio: A Static and a Dynamic Analytical Framework,' International Business Research, 6(6), 162-180.

Sarros, J. (1993), Leadership Report 1993: Australian Trends in Corporate Leadership, Leadership Research Unit. Management Monograph Series, Syme Business School Frankston.

Sedzro, K. T. (2010), 'A Unifying Approach for Comparing One-time Payouts and Recurring Dividends,' Global Journal of Business Research, 4(2), 141-154.

Setia-Atmaja, L. (2010), 'Dividend and debt policies of family controlled firms: The impact of board independence,' International Journal of Managerial Finance, 6(2), 128-142.

Sharma, V. (2011), 'Independent directors and the propensity to pay dividends, 'Journal of Corporate Finance, 17(4), 1001-1015. 
Shivdasani, A. (1993), 'Board composition, ownership structure, and hostile takeovers,' Journal of Accounting and Economics, 16(1), 167-198.

Shleifer, A. and R. W. Vishny (1986), 'Large shareholders and Corporate control,' Journal of Political Economy, 94(3), 458-461.

Shleifer, A. and R. W. Vishny (1997), 'A survey of corporate governance,' The Journal of Finance, 52(2), 737-783.

Short, H., H. Zhang and K. Keasey (2002), 'The link between dividend policy and institutional ownership, 'Journal of Corporate Finance, 8(2), 105-122.

Shrader, C., V. Blackburn and P. Iles (1997), 'Women in management and firm financial performance: an explorative study,' Journal of Managerial Issues, 9(3), 355-372.

Srinidhi, B., F. A. Gul and J. Tsui (2011), 'Female Directors and Earnings Quality,' Contemporary Accounting Research, 28(5), 1610-1644.

Stoughton, N. M. and J. Zechner (1998), 'IPO-mechanisms, monitoring and ownership structure,' Journal of Financial Economics, 49(1), 45-77.

Talpsepp, T. (2013), 'Does Gender and Age Affect Investor Performance and the Disposition Effect?' Research in Economics and Business: Central and Eastern Europe, 2(1), 76-93.

Taylor, W. (1990), 'Can big owners make a difference?' Harvard Review, 68(5), 70-82.

Terjesen, S., R. Sealy and V. Singh (2009), 'Women directors on corporate boards: A review and research agenda,' Corporate Governance: An International Review, 17(3), 320-337.

Unified Code of Corporate Governance (CUBG). (2006), Informe del grupo especial de trabajo sobre buen gobierno de las sociedades cotizadas. Comite' Conthe: Madrid.

Van Nuys, K. (1993), 'Corporate governance through the proxy process: evidence from the 1989 Honeywell proxy solicitation,' Journal of Financial Economics, 34(1), 101-132.

Van Pelt, T. (2013), 'The effect of board characteristics on dividend policy,' Unpublished working paper, Tilburg School of Economics and Management, Department of Finance. Tilburg University:The Netherlands, pp. 1-62.

Varma, R. (2001), 'The role of institutional investors in equity financing and corporate monitoring,' Journal of Business and Economic Studies, 7(1), 39-53.

Vermeulen, M. (2011), 'Dividend payout and future earnings growth: a South African study,' Doctoral dissertation, Stellenbosch: Stellenbosch University.

Vilkinas, T. and G. Cartan (1993), 'Competencies of Australian women managers,' Women in Management Review, 8(3), 31-35.

Wan-Hussin, W. N. (2009), 'The impact of family-firm structure and Board composition on Corporate transparency: evidence based on segment disclosures in Malaysia,' The International Journal of Accounting, 44(4), 313-333.

Webb, E. (2004), 'An examination of socially responsible firms' board structure,' Journal of Management and Governance, 8(3), 255-277.

Wei, L., F. Xiaoqing and C. Xiaopin (2011), 'Board Independence and Accounting Conservatism: Evidence Based on Listed Companies in China,' In Management and Service Science (MASS), 2011 International Conference on (pp. 1-5). IEEE.

Weisbach, M. S. (1988), 'Outside directors and CEO turnover,' Journal of Financial Economics, 20(2), 431-460.

Wellalage, N., F. Fauzi and G. Wang (2012), 'Corporate governance and cash dividend policy: Evidence from Chinese IPOs,' Unpublished working paper, 1-24.

Xie, B., W. N. Davidson and P. J. DaDalt (2003), 'Earnings management and Corporate Governance: the roles of the Board and the Audit Committee,' Journal of Corporate Finance, 9(3), 295-316. 
Ye, K., R. Zhang and Z. Rezaee (2010), 'Does top executive gender diversity affect earnings quality? A large sample analysis of Chinese listed firms,' Advances in Accounting, 26(1), 47-54.

Yermack, D. (1996), 'Higher valuation of companies with a small board of directors,' Journal of Financial Economics, 40(2), 185-213.

Zeckhauser, R. J. and J. Pound (1990), 'Are large shareholders effective monitors? An investigation of share ownership and corporate performance. In Asymmetric information, corporate finance, and investment,' University of Chicago Press, 149-180.

Zhang, H. (2008), 'Corporate governance and dividend policy: A comparison of Chinese firms listed in Hong Kong and in the Mainland,' China Economic Review, 19(3), 437-459.

Zhou, P. and W. Ruland (2006), 'Dividend payout and future earnings growth,' Financial Analysts Journal, 62(3), 58-69. 
TABLE 1

Variable Definition

\begin{tabular}{llc}
\hline Variables & Description & $\begin{array}{c}\text { Expected } \\
\text { Sign }\end{array}$ \\
\hline PERWDBD & Total number of women in BD/Total members of BD & + \\
PERIWDBD & Total number of independent women in BD/Total number of members of BD & + \\
PERINSWDBD & Total number of institutional women in BD/Total number of members of BD & $+/-$ \\
PEREWDBD & Total number of insider women in BD/Total number of members of BD & - \\
OWNWOMBD & Percentage of shares held by women directors on BD & + \\
OWNCON & The ownership concentration of the firm & - \\
IO & Rate of assets growth & - \\
OWNMANG & Percentage of stocks owned by directors & - \\
LEV & Ratio of book value of debt over total assets & - \\
ROA & Ratio of earnings before interest and taxation (EBIT)/Total book assets & + \\
ROE & Ratio of net income/stockholder's equity & + \\
FIRMSIZE & Total assets (log) & + \\
BDSIZE & Total number of directors serving on board & + \\
INDP & Proportion of independent directors on BD & + \\
INST & Proportion of institutional directors on BD & $+/-$ \\
\hline
\end{tabular}


TABLE 2

Main Descriptive Statistics

\begin{tabular}{lcccccc}
\hline \multicolumn{2}{c}{ a) Continuos Variables } & & & & & \\
\hline \multicolumn{1}{c}{ Variables } & N & Mean & Std. Dev. & Perc. 25 & Perc. 50 & Perc. 75 \\
\hline DPY2 & 894 & 15.648 & 21.724 & 0.000 & 6.410 & 25.407 \\
DPY3 & 894 & 5.684 & 5.391 & 0.000 & 7.477 & 10.793 \\
PERWDBD & 894 & 7.808 & 9.424 & 0.000 & 5.882 & 12.500 \\
PERIWDBD & 894 & 2.880 & 5.772 & 0.000 & 0.000 & 0.000 \\
PERINSWDBD & 894 & 3.797 & 6.977 & 0.000 & 0.000 & 7.143 \\
PEREWDBD & 894 & 0.737 & 3.229 & 0.000 & 0.000 & 0.000 \\
OWNWOMBD & 894 & 2.438 & 9.402 & 0.000 & 0.000 & 0.006 \\
OWNCON & 894 & 41.723 & 28.645 & 15.148 & 40.302 & 64.620 \\
IO & 894 & 22.418 & 150.638 & -3.842 & 34.572 & 15.803 \\
OWNMANG & 894 & 26.814 & 26.751 & 1.381 & 18.445 & 49.935 \\
LEV & 894 & 60.256 & 121.915 & 35.093 & 56.040 & 71.186 \\
ROA & 894 & -2.318 & 213.080 & -0.973 & 3.127 & 8.339 \\
ROE & 894 & -10.067 & 247.404 & -0.144 & 8.307 & 18.103 \\
FIRMSIZE & 894 & 13.280 & 1.835 & 11.952 & 13.157 & 14.500 \\
BDSIZE & 894 & 10.712 & 3.679 & 8.000 & 10.000 & 12.000 \\
INDP & 894 & 32.490 & 19.380 & 21.053 & 30.769 & 42.857 \\
INST & 894 & 44.591 & 25.079 & 27.272 & 44.444 & 60.000 \\
\hline
\end{tabular}

b) Dummies Variables

\begin{tabular}{lcccc}
\hline & $\mathbf{0}$ & $\mathbf{\%}(\mathbf{0})$ & $\mathbf{1}$ & $\mathbf{\%}(\mathbf{1})$ \\
\hline DPY1 & 394 & $44 \%$ & 500 & $56 \%$ \\
\hline
\end{tabular}

Mean, standard deviation and percentiles of the main variables. DPY2 is cash dividends on common stock divided by the market value of common stock of firms; DPY3 is the logarithm of the total amount of dividends paid per share in the accounting year; PERWDBD is the percentage of female directors on the BD; PERIWDBD is the percentage of independent female directors on the BD; PERINSWDBD is the percentage of institutional directors; PEREWDBD is the percentage of executive directors on the BD; OWNWOMBD is the percentage of shares held by female directors on the BD; OWNCON is the percentage of shares held by shareholders holding at least $5 \%$ of the firm's stock; IO is the rate of assets growth; OWNMANG is the percentage of stocks owned by directors; LEV is the ratio of book value of debt over total book assets; ROA is the ratio of earnings before interest and taxation (EBIT) over total book assets; ROE is the net income divided by stockholder's equity; FIRMSIZE is the natural logarithm of total assets; BDSIZE is calculated as the total number of directors on the board; INDP is the proportion of independent directors on BD; INST is the proportion of institutional directors on BD; DPY1 is equal to 1 if the company pays dividends and 0 , otherwise. 
TABLE 3

Means Comparison Test. Model 1

\begin{tabular}{lcccc}
\hline \multicolumn{1}{c}{ Variables } & $\begin{array}{c}\text { DPY1 }(=1) \\
\text { Mean }\end{array}$ & $\begin{array}{c}\text { DPY1 }(=0) \\
\text { Mean }\end{array}$ & $\begin{array}{c}\text { Mean } \\
\text { Difference }\end{array}$ & p. value \\
\hline PERWDBD & 7.887 & 7.709 & 0.178 & 0.390 \\
PERIWDBD & 3.405 & 2.225 & 1.180 & 0.001 \\
PERINSWDBD & 3.583 & 4.064 & -0.481 & 0.152 \\
PEREWDBD & 0.571 & 0.946 & -0.375 & 0.042 \\
OWNWOMBD & 2.751 & 2.047 & 0.794 & 0.133 \\
\hline
\end{tabular}

DPY1 is equal to 1 if the company pays dividends and 0, otherwise; PERWDBD is the percentage of female directors on the BD; PERIWDBD is the percentage of independent female directors on the BD; PERINSWDBD is the percentage of institutional directors; PEREWDBD is the percentage of executive directors on the BD; OWNWOMBD is the percentage of shares held by female directors on the BD.

TABLE 4

Means Comparison Test. Model 2

\begin{tabular}{lcccc}
\hline Variables & $\begin{array}{c}\text { DPY2 }(>=6,40) \\
\text { Mean }\end{array}$ & $\begin{array}{c}\text { DPY2 }(<6,40) \\
\text { Mean }\end{array}$ & $\begin{array}{c}\text { Mean } \\
\text { Difference }\end{array}$ & p. value \\
\hline PERWDBD & 8.117 & 7.509 & 0.608 & 0.167 \\
PERIWDBD & 3.586 & 2.200 & 1.386 & 0.000 \\
PERINSWDBD & 3.619 & 3.968 & -0.349 & 0.227 \\
PEREWDBD & 0.597 & 0.872 & -0.275 & 0.101 \\
OWNWOMBD & 2.952 & 1.942 & 1.010 & 0.054 \\
\hline
\end{tabular}

DPY2 is cash dividends on common stock divided by the market value of common stock of firms; PERWDBD is the percentage of female directors on the BD; PERIWDBD is the percentage of independent female directors on the BD; PERINSWDBD is the percentage of institutional directors; PEREWDBD is the percentage of executive directors on the BD; OWNWOMBD is the percentage of shares held by female directors on the BD.

TABLE 5

Means Comparison Test. Model 3

\begin{tabular}{lcccc}
\hline \multicolumn{1}{c}{ Variables } & $\begin{array}{c}\text { DPY3 }(>=7,48) \\
\text { Mean }\end{array}$ & $\begin{array}{c}\text { DPY3 }(<7,48) \\
\text { Mean }\end{array}$ & $\begin{array}{c}\text { Mean } \\
\text { Difference }\end{array}$ & p. value \\
\hline PERWDBD & 7.785 & 7.829 & -0.044 & 0.472 \\
PERIWDBD & 3.702 & 2.085 & 1.617 & 0.000 \\
PERINSWDBD & 3.273 & 4.304 & -1.030 & 0.013 \\
PEREWDBD & 0.555 & 0.914 & -0.359 & 0.048 \\
OWNWOMBD & 2.694 & 2.190 & 0.504 & 0.211 \\
\hline
\end{tabular}

DPY3 is the logarithm of the total amount of dividends paid per share in the accounting year; PERWDBD is the percentage of female directors on the BD; PERIWDBD is the percentage of independent female directors on the BD; PERINSWDBD is the percentage of institutional directors; PEREWDBD is the percentage of executive directors on the BD; OWNWOMBD is the percentage of shares held by female directors on the BD. 
TABLE 6

\section{Correlation Matrix}

\begin{tabular}{|c|c|c|c|c|c|c|c|c|c|c|c|c|c|c|c|c|c|}
\hline & DPY1 & DPY2 & DPY3 & PERWDBD & PERIWDBD & PERINSWDBD & PEREWDBD & OWNWOMBD & OWNCON & IO & OWNMANG & LEV & ROA & ROE & FIRMSIZE & BDSIZE & INDP \\
\hline DPY2 & $0.900 * * *$ & & & & & & & & & & & & & & & & \\
\hline DPY3 & $0.894 * * *$ & $0.925 * * *$ & & & & & & & & & & & & & & & \\
\hline PERWDBD & 0.002 & 0.038 & 0.026 & & & & & & & & & & & & & & \\
\hline PERIWDBD & $0.089 * * *$ & $0.143 * * *$ & $0.180^{* * * *}$ & $0.531 * * *$ & & & & & & & & & & & & & \\
\hline PERINSWDBD & -0.014 & -0.007 & -0.030 & $0.658^{* * * *}$ & $-0.059 *$ & & & & & & & & & & & & \\
\hline PEREWDBD & -0.048 & $-0.065 *$ & $-0.093^{* * * *}$ & $0.300 * * *$ & $-0.116 * * *$ & $0.066 * *$ & & & & & & & & & & & \\
\hline OWNWOMBD & $0.058 *$ & 0.053 & 0.029 & $0.650 * *$ & $0.152 * * *$ & $0.561 * * *$ & $0.312 * * *$ & & & & & & & & & & \\
\hline OWNCON & $0.057^{*}$ & $0.076^{* *}$ & $0.101^{* * *}$ & $-0.081^{* *}$ & 0.008 & -0.040 & 0.042 & $-0.186^{* * * *}$ & & & & & & & & & \\
\hline IO & $0.237^{* * * *}$ & $0.180^{* * * *}$ & $0.207 * * *$ & -0.054 & 0.022 & -0.020 & -0.052 & -0.001 & 0.030 & & & & & & & & \\
\hline OWNMANG & $-0.171^{* * * *}$ & $-0.197 * * *$ & $-0.282^{* * * *}$ & $0.162 * * *$ & $-0.204 * * *$ & $0.271 * * *$ & $0.226 * * *$ & $0.308 * * *$ & $-0.269 * * *$ & -0.017 & & & & & & & \\
\hline LEV & $-0.107^{* * * *}$ & -0.047 & -0.036 & -0.006 & $-0.110^{* * * *}$ & $0.077^{* *}$ & 0.025 & 0.048 & $0.060^{*}$ & -0.008 & $0.168^{* * * *}$ & & & & & & \\
\hline ROA & $0.573 * * * *$ & $0.575 * * *$ & $0.567 * * * *$ & -0.053 & $0.098 * * *$ & $-0.094 *$ & $-0.058^{*}$ & -0.012 & 0.028 & $0.270^{* * * *}$ & $-0.161 * * *$ & $-0.257^{* * * *}$ & & & & & \\
\hline ROE & $0.554^{* * * *}$ & $0.575 * * *$ & $0.580^{* * * *}$ & -0.022 & $0.058^{*}$ & -0.046 & 0.006 & 0.033 & 0.038 & $0.246 * * *$ & $-0.076^{* *}$ & 0.036 & $0.755^{* * * *}$ & & & & \\
\hline FIRMSIZE & $0.327 * * *$ & $0.407 * * *$ & $0.548^{* * * *}$ & 0.031 & $0.192 * * *$ & -0.005 & $-0.073^{* *}$ & -0.039 & $0.230 * * *$ & $0.167 * * *$ & $-0.251^{* * * *}$ & $0.290 * * *$ & $0.084 * *$ & $0.220 * * *$ & & & \\
\hline BDSIZE & $0.295 * * *$ & $0.339 * * *$ & $0.416 * * *$ & -0.022 & $0.145 * * *$ & 0.016 & $-0.136 * * *$ & -0.012 & $0.091 * * *$ & $0.154 * * *$ & $-0.172 * * *$ & $0.064 *$ & $0.098 * * *$ & $0.153 * * *$ & $0.611^{* * *}$ & & \\
\hline INDP & 0.039 & $0.075 * *$ & $0.125 * * *$ & 0.009 & $0.341 * * *$ & $-0.252 * * *$ & $-0.128 * * *$ & $-0.126 * * *$ & $-0.085^{* * *}$ & 0.026 & -0.270 **** & $-0.172 * * * *$ & $0.093 * * *$ & 0.037 & $0.100 * * *$ & $-0.090 * * *$ & \\
\hline INST & $0.114 * * * *$ & $0.114 * * *$ & $0.077^{* * *}$ & 0.054 & $-0.104 * * *$ & $0.274 * * *$ & $-0.128 * * *$ & $0.116 * * *$ & $0.147 * * * *$ & 0.021 & $0.087 * * *$ & $0.075^{* *}$ & -0.009 & 0.025 & $0.125 * * *$ & $0.220 * * *$ & $-0.562 * * *$ \\
\hline
\end{tabular}

DPY1 is a dummy variable equal to 1 if the company pays dividends and 0, otherwise; DPY2 is calculated as the ratio between cash dividends on common stock ant the market value of common stock of firms; DPY3 is the logarithm of the total amount of dividend paid per share in the accounting year; PERWDBD is the percentage of female directors on the BD; PERIWDBD is the percentage of independent female directors on the BD; PERINSWDBD is the percentage of institutional directors; PEREWDBD is the percentage of executive directors on the BD; OWNWOMBD is the percentage of shares held by female directors on the BD; OWNCON is the percentage of shares held by shareholders holding at least 5\% of the firm's stock; IO is the rate of assets growth; OWNMANG is the percentage of stocks owned by directors; LEV is the ratio of book value of debt over total book assets; ROA is the ratio of earnings before interest and taxation (EBIT) over total book assets; ROE is the net income divided by stockholder's equity; FIRMSIZE is the natural logarithm of total assets; BDSIZE is calculated as the total number of directors on the board; INDP is the proportion of independent directors on BD; INST is the proportion of institutional directors on BD. ${ }^{*} \mathrm{p}<0.1 ; * * \mathrm{p}<0.05 ; * * * \mathrm{p}<0.01$ 
TABLE 7

Regression models

\begin{tabular}{|c|c|c|c|c|}
\hline Variables & $\begin{array}{c}\text { Expected } \\
\text { Sign }\end{array}$ & $\begin{array}{l}\text { Model } 1 \text { DPY1 } \\
\text { Estimated } \\
\text { coefficient } \\
\text { (p-value) }\end{array}$ & $\begin{array}{c}\text { Model } 2 \text { DPY2 } \\
\text { Estimated } \\
\text { coefficient } \\
\text { (p-value) }\end{array}$ & $\begin{array}{c}\text { Model } 3 \text { DPY3 } \\
\text { Estimated } \\
\text { coefficient } \\
\text { (p-value) }\end{array}$ \\
\hline PERWDBD & + & $\begin{array}{l}6.738^{*} \\
(0.083)\end{array}$ & $\begin{array}{c}5.965 \\
(0.754)\end{array}$ & $\begin{array}{c}11.479 * \\
(0.097)\end{array}$ \\
\hline PERIWDBD & + & $\begin{array}{c}4.067 \\
(0.322)\end{array}$ & $\begin{array}{c}53.576 \\
(0.420)\end{array}$ & $\begin{array}{c}7.598 \\
(0.291)\end{array}$ \\
\hline PERINSWDBD & $+/-$ & $\begin{array}{c}-7.638^{*} \\
(0.069)\end{array}$ & $\begin{array}{c}-3.286 * * \\
(0.039)\end{array}$ & $\begin{array}{c}-7.333^{*} \\
(0.085)\end{array}$ \\
\hline PEREWDBD & - & $\begin{array}{l}-6.275 \\
(0.180)\end{array}$ & $\begin{array}{c}-13.918 \\
(0.554)\end{array}$ & $\begin{array}{l}-3.501 \\
(0.708)\end{array}$ \\
\hline OWNWOMBD & + & $\begin{array}{c}1.300 \\
(0.252)\end{array}$ & $\begin{array}{l}14.800 * \\
(0.090)\end{array}$ & $\begin{array}{c}6.600 * * * \\
(0.008)\end{array}$ \\
\hline OWNCON & - & $\begin{array}{l}-0.271 \\
(0.379)\end{array}$ & $\begin{array}{l}-1.657 \\
(0.384)\end{array}$ & $\begin{array}{l}-1.087 \\
(0.197)\end{array}$ \\
\hline IO & - & $\begin{array}{c}-0.301 * * \\
(0.019)\end{array}$ & $\begin{array}{c}-0.878 * * \\
(0.023)\end{array}$ & $\begin{array}{c}-0.128 * \\
(0.081)\end{array}$ \\
\hline OWNMANG & - & $\begin{array}{c}-0.610^{*} \\
(0.073)\end{array}$ & $\begin{array}{c}-8.158 * * \\
(0.047)\end{array}$ & $\begin{array}{l}-1.209 \\
(0.257)\end{array}$ \\
\hline LEV & - & $\begin{array}{c}-1.799 * * * \\
(0.000)\end{array}$ & $\begin{array}{c}0.189 \\
(0.344)\end{array}$ & $\begin{array}{c}0.113 \\
(0.370)\end{array}$ \\
\hline $\mathrm{ROA}$ & + & $\begin{array}{c}1.199 \\
(0.107)\end{array}$ & $\begin{array}{c}0.218 \\
(0.273)\end{array}$ & $\begin{array}{c}0.019 \\
(0.758)\end{array}$ \\
\hline ROE & + & $\begin{array}{c}1.197 * * * \\
(0.000)\end{array}$ & $\begin{array}{c}0.732 * * \\
(0.032)\end{array}$ & $\begin{array}{c}0.009 \\
(0.831)\end{array}$ \\
\hline FIRMSIZE & + & $\begin{array}{c}0.471 * * * \\
(0.000)\end{array}$ & $\begin{array}{c}2.877 * * * \\
(0.000)\end{array}$ & $\begin{array}{c}0.722 * * \\
(0.011)\end{array}$ \\
\hline BDSIZE & + & $\begin{array}{l}0.060 * \\
(0.060)\end{array}$ & $\begin{array}{c}0.568 \\
(0.197)\end{array}$ & $\begin{array}{c}0.025 \\
(0.682)\end{array}$ \\
\hline INDP & + & $\begin{array}{c}0.011 \\
(0.983)\end{array}$ & $\begin{array}{c}2.982 \\
(0.133)\end{array}$ & $\begin{array}{c}0.339 \\
(0.715)\end{array}$ \\
\hline INST & $+/-$ & $\begin{array}{c}1.208^{* * *} \\
(0.005)\end{array}$ & $\begin{array}{c}11.099 * \\
(0.084)\end{array}$ & $\begin{array}{c}0.291 \\
(0.741)\end{array}$ \\
\hline
\end{tabular}

Estimated coefficients. In Model 1, the dependent variable is DPY1, which is a dummy variable equal to 1 if the company pays dividends and 0, otherwise; in Model 2, the dependent variable is DPY2, which is calculated as the ratio between cash dividends on common stock ant the market value of common stock of firms; in Model 3, the dependent variable is DPY3, which is the logarithm of the total amount of dividend paid per share in the accounting year; PERWDBD is the percentage of female directors on the BD; PERIWDBD is the percentage of independent female directors on the BD; PERINSWDBD is the percentage of institutional directors; PEREWDBD is the percentage of executive directors on the BD; OWNWOMBD is the percentage of shares held by female directors on the BD; OWNCON is the percentage of shares held by shareholders holding at least $5 \%$ of the firm's stock; IO is the rate of assets growth; OWNMANG is the percentage of stocks owned by directors; LEV is the ratio of book value of debt over total book assets; ROA is the ratio of earnings before interest and taxation (EBIT) over total book assets; ROE is the net income divided by stockholder's equity; FIRMSIZE is the natural logarithm of total assets; BDSIZE is calculated as the total number of directors on the board; INDP is the proportion of independent directors on BD; INST is the proportion of institutional directors on BD. * $\mathrm{p}<0.1 ; * * \mathrm{p}<0.05 ; * * * \mathrm{p}<0.01$ 
TABLE 8

Regression models with ROA and ROE positive

\begin{tabular}{|c|c|c|c|c|}
\hline Variables & $\begin{array}{l}\text { Expected } \\
\text { Sign }\end{array}$ & $\begin{array}{c}\text { Model } 1 \text { DPY1 } \\
\text { Estimated } \\
\text { coefficient } \\
\text { (p-value) }\end{array}$ & $\begin{array}{c}\text { Model } 2 \text { DPY2 } \\
\text { Estimated } \\
\text { coefficient } \\
\text { (p-value) }\end{array}$ & $\begin{array}{c}\text { Model } 3 \text { DPY3 } \\
\text { Estimated } \\
\text { coefficient } \\
\text { (p-value) }\end{array}$ \\
\hline PERWDBD & + & $\begin{array}{c}2.980 * * * \\
(0.001)\end{array}$ & $\begin{array}{l}50.174 \\
(0.165)\end{array}$ & $\begin{array}{c}20.208^{* *} * \\
(0.021)\end{array}$ \\
\hline PERIWDBD & + & $\begin{array}{c}2.499 * * * \\
(0.007)\end{array}$ & $\begin{array}{c}62.717 * \\
(0.072)\end{array}$ & $\begin{array}{c}14.391 \\
(0.112)\end{array}$ \\
\hline PERINSWDBD & $+/-$ & $\begin{array}{c}-2.657 * * * \\
(0.006)\end{array}$ & $\begin{array}{c}-83.547 * \\
(0.090)\end{array}$ & $\begin{array}{c}-17.580 * \\
(0.064)\end{array}$ \\
\hline PEREWDBD & - & $\begin{array}{c}-2.561 * * \\
(0.024)\end{array}$ & $\begin{array}{c}-98.338 * \\
(0.064)\end{array}$ & $\begin{array}{c}-20.814^{*} \\
(0.064)\end{array}$ \\
\hline OWNWOMBD & + & $\begin{array}{c}8.410 \\
(0.712)\end{array}$ & $\begin{array}{c}14.400 \\
(0.341)\end{array}$ & $\begin{array}{c}1.100 \\
(0.617)\end{array}$ \\
\hline OWNCON & - & $\begin{array}{l}-0.022 \\
(0.705)\end{array}$ & $\begin{array}{c}-10.771 \\
(0.215)\end{array}$ & $\begin{array}{r}-0.372 \\
(0.529)\end{array}$ \\
\hline IO & - & $\begin{array}{c}-0.074 * * * \\
(0.002)\end{array}$ & $\begin{array}{c}0.409 \\
(0.641)\end{array}$ & $\begin{array}{c}-0.974 * * * \\
(0.000)\end{array}$ \\
\hline OWNMANG & - & $\begin{array}{l}-0.057 \\
(0.421)\end{array}$ & $\begin{array}{c}-11.801 \\
(0.226)\end{array}$ & $\begin{array}{c}-1.458 * * \\
(0.037)\end{array}$ \\
\hline LEV & - & $\begin{array}{c}-0.153 * * \\
(0.039)\end{array}$ & $\begin{array}{c}6.094 \\
(0.568)\end{array}$ & $\begin{array}{c}-2.534 * * * \\
(0.001)\end{array}$ \\
\hline $\mathrm{ROA}$ & + & $\begin{array}{l}-0.047 \\
(0.201)\end{array}$ & $\begin{array}{c}0.340 \\
(0.766)\end{array}$ & $\begin{array}{l}-0.156 \\
(0.668)\end{array}$ \\
\hline ROE & + & $\begin{array}{c}0.227 * * * \\
(0.001)\end{array}$ & $\begin{array}{c}17.243^{*} \\
(0.091)\end{array}$ & $\begin{array}{c}4.157 * * * \\
(0.000)\end{array}$ \\
\hline FIRMSIZE & + & $\begin{array}{c}0.068 * * * \\
0.000)\end{array}$ & $\begin{array}{l}-0.699 \\
(0.816)\end{array}$ & $\begin{array}{c}1.447 * * * \\
(0.000)\end{array}$ \\
\hline BDSIZE & + & $\begin{array}{c}0.004 \\
(0.465)\end{array}$ & $\begin{array}{c}-0.232 \\
(0.779)\end{array}$ & $\begin{array}{c}0.016 \\
(0.779)\end{array}$ \\
\hline INDP & + & $\begin{array}{c}-0.008 \\
(0.940)\end{array}$ & $\begin{array}{l}-1.546 \\
(0.911)\end{array}$ & $\begin{array}{l}-0.117 \\
(0.914)\end{array}$ \\
\hline INST & $+/-$ & $\begin{array}{c}0.298 * * * \\
(0.000)\end{array}$ & $\begin{array}{c}6.815 \\
(0.571)\end{array}$ & $\begin{array}{c}2.165 * * * \\
(0.007)\end{array}$ \\
\hline
\end{tabular}

Estimated coefficients. In Model 1, the dependent variable is DPY1, which is a dummy variable equal to 1 if the company pays dividends and 0, otherwise; in Model 2, the dependent variable is DPY2, which is calculated as the ratio between cash dividends on common stock ant the market value of common stock of firms; in Model 3, the dependent variable is DPY3, which is the logarithm of the total amount of dividend paid per share in the accounting year; PERWDBD is the percentage of female directors on the BD; PERIWDBD is the percentage of independent female directors on the BD; PERINSWDBD is the percentage of institutional directors; PEREWDBD is the percentage of executive directors on the BD; OWNWOMBD is the percentage of shares held by female directors on the BD; OWNCON is the percentage of shares held by shareholders holding at least $5 \%$ of the firm's stock; IO is the rate of assets growth; OWNMANG is the percentage of stocks owned by directors; LEV is the ratio of book value of debt over total book assets; ROA is the ratio of earnings before interest and taxation (EBIT) over total book assets; ROE is the net income divided by stockholder's equity; FIRMSIZE is the natural logarithm of total assets; BDSIZE is calculated as the total number of directors on the board; INDP is the proportion of independent directors on BD; INST is the proportion of institutional directors on BD. * $\mathrm{p}<0.1 ; * * \mathrm{p}<0.05 ; * * * \mathrm{p}<0.01$ 
